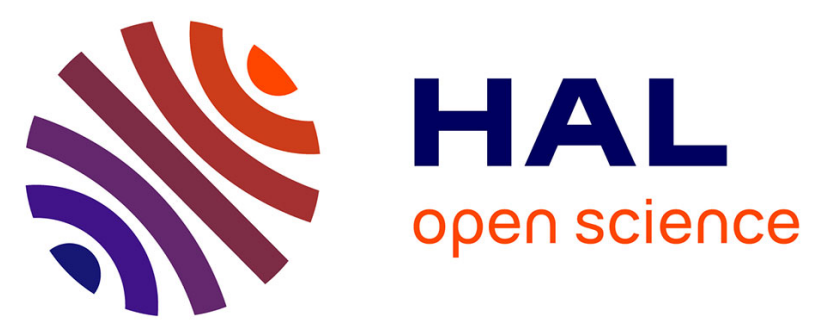

\title{
Ocean redox structure across the Late Neoproterozoic Oxygenation Event: A nitrogen isotope perspective
} Magali P Ader, Pierre P Sansjofre, Galen P Halverson, Vincent P Busigny, Ricardo I. F. Trindade, Marcus P Kunzmann, Afonso C. R. Nogueira

\section{- To cite this version:}

Magali P Ader, Pierre P Sansjofre, Galen P Halverson, Vincent P Busigny, Ricardo I. F. Trindade, et al.. Ocean redox structure across the Late Neoproterozoic Oxygenation Event: A nitrogen isotope perspective. Earth and Planetary Science Letters, 2014, 396, pp.1 - 13. 10.1016/j.epsl.2014.03.042 . hal-01388690

\section{HAL Id: hal-01388690 \\ https://hal.science/hal-01388690}

Submitted on 27 Oct 2016

HAL is a multi-disciplinary open access archive for the deposit and dissemination of scientific research documents, whether they are published or not. The documents may come from teaching and research institutions in France or abroad, or from public or private research centers.
L'archive ouverte pluridisciplinaire HAL, est destinée au dépôt et à la diffusion de documents scientifiques de niveau recherche, publiés ou non, émanant des établissements d'enseignement et de recherche français ou étrangers, des laboratoires publics ou privés. 
17 *Corresponding author:

18 Magali Ader

19 Équipe de géochimie des isotopes stables, Institut de Physique du Globe de Paris, 1 rue Jussieu, 2075238 Paris, France.

21 Phone number: +33 (0)1 83957506

22 e-mail address: ader@,ipgp.fr

23

\section{nitrogen isotope perspective}

7154 CNRS, 1 rue Jussieu, 75238 Paris, France

${ }^{\mathrm{b}}$ Departamento de Geofísica, Instituto de Astronomia, Geofísica e Ciências Atmosféricas, Universidade de São Paulo, Rua do Matão 1226, 05508-900 São Paulo, Brazil

${ }^{c}$ now at Laboratoire Domaines Océaniques, Université de Bretagne Occidentale, UMR 6538,

${ }^{\mathrm{d}}$ Department of Earth and Planetary Sciences/Geotop,

${ }^{\mathrm{e}}$ Faculdade de Geologia, Instituto de Geociências, Universidade Federal do Pará, CEP 66.075-110, Belém, Brazil.
Keywords: Nitrogen isotopes, Neoproterozoic, ocean oxygenation, nitrogen biogeochemical cycle, paleoceanography. 


\section{Abstract}

28 The end of the Neoproterozoic Era (1000 to $541 \mathrm{Ma}$ ) is widely believed to have seen the

29 transition from a dominantly anoxic to an oxygenated deep ocean. This purported redox

30 transition appears to be closely linked temporally with metazoan radiation and extraordinary

31 perturbations to the global carbon cycle. However, the geochemical record of this transition is

32 not straightforward, and individual data sets have been variably interpreted to indicate full

33 oxygenation by the early Ediacaran Period (635 to $541 \mathrm{Ma}$ ) and deep ocean anoxia persevering

34 as late as the early Cambrian. Because any change in marine redox structure would have

35 profoundly impacted nitrogen nutrient cycling in the global ocean, the $\mathrm{N}$ isotope signature of

36 sedimentary rocks $\left(\delta^{15} \mathrm{~N}_{\text {sed }}\right)$ should reflect the Neoproterozoic deep-ocean redox transition. We

37 present new $\mathrm{N}$ isotope data from Amazonia, northwest Canada, northeast Svalbard, and South

38 China that span the Cryogenian glaciations ( $\sim 50$ to $580 \mathrm{Ma})$. These and previously published

39 data reveal a $\mathrm{N}$-isotope distribution that closely resembles modern marine sediments, with a

40 mode in $\delta^{15} \mathrm{~N}$ close to $4 \%$ and range from -4 and $+11 \%$. No apparent change is seen between the

41 Cryogenian and Ediacarian. Data from earlier Proterozoic samples show a similar distribution,

42 but shifted slightly towards more negative $\delta^{15} \mathrm{~N}$ values and with a wider range. The most

43 parsimonious explanation for the similarity of these $\mathrm{N}$-isotope distribution is that as in the

44 modern ocean, nitrate (and hence $\mathrm{O}_{2}$ ) was stable in most of the middle-late Neoproterozoic 45 ocean, and possibly much of Proterozoic Eon. However, nitrate would likely have been depleted 46 in partially restricted basins and oxygen minimum zones (OMZs), which may have been more 47 widespread than in the modern ocean. 


\section{Introduction}

50 It is widely argued that the appearance of animals in the geological record is linked to a major 51 step in the oxygenation of Earth's surface environment, known as the Neoproterozoic

52 Oxygenation Event (NOE) (Canfield et al., 2007, 2008; Och and Shields-Zhou, 2012; Scott et al., 53 2008). The NOE is more difficult to document in the geological record than its early

54 Paleoproterozoic counterpart, the Great Oxidation Event (GOE), whose onset is well established 55 based on the sedimentary record of redox-sensitive detrital minerals and mass independent 56 fractionation of sulfur isotopes (e.g. Farquhar et al., 2000; Lyons et al., 2014). Although the NOE 57 has not been formally defined, one criterion is the timing of ventilation of the deep ocean with 58 sufficient dissolved oxygen to accommodate the earliest animals (Och and Shields-Zhou, 2012).

59 Whereas the cause-and-effect relationship between oxygenation and animal evolution and the 60 oxygen threshold required for early animals are still debated (e.g., Butterfield, 2009; Sperling et 61 al., 2013), eukaryotic diversification and the oxygenation of the environment must have been 62 closely coupled through a complex network of biogeochemical feedbacks linked through the 63 origin, export, decay and burial of organic matter (Butterfield, 2009; Close et al., 2011; Logan et 64 al., 1995; Pawlowska et al., 2013).

65 Iron speciation data from Neoproterozoic mudstones suggest a transition from dominantly anoxic 66 and ferruginous deep oceans with prevalent sulfidic (euxinic) conditions in continental margin 67 settings (Planavsky et al., 2011; Poulton and Canfield, 2011) to dominantly anoxic and 68 ferruginous deep oceans with only occasional evidence for euxinic conditions in the early69 middle Neoproterozoic (Canfield et al., 2008), followed by deep-ocean ventilation in the late 70 Ediacaran (Canfield et al., 2007). However, these data only provide information about local 71 depositional redox conditions and do not bear directly on the state of the deep ocean. Trace metal 
72 abundances (Mo, $\mathrm{U}, \mathrm{V}$, and $\mathrm{Cr}$ ) in euxinic sediments, although sensitive to local conditions, are

73 also strongly dependent on the volume of oxygenated water masses, hence they bear on global

74 redox conditions in the oceans (Algeo and Rowe, 2012). A series of separate studies and

75 compilations of trace metal data have been published recently. All show a dramatic increase in

76 abundances in the Ediacaran first interpreted to record deep ocean ventilation (635-541 Ma;

77 Scott et al., 2008; Och and Shields-Zhou, 2012; Sahoo et al., 2012; Partin et al., 2013), broadly

78 consistent with iron speciation data. Yet, data from some individual basins variably indicate

79 persistently anoxic (Li et al., 2010; Johnston et al., 2013) versus oxygenated (Johnston et al.,

80 2012; Sansjofre et al., 2014) bottom-waters throughout most of the Ediacaran Period. Other data

81 imply widespread oxygen-deficient conditions in the earliest Cambrian (e.g. Schroder and

82 Grotzinger, 2007; Cremonese et al., 2013) despite the appearance of complexly burrowing

83 bilaterians. An emerging model is that anoxic conditions on continental platforms was locally

84 controlled (Kah and Bartley, 2011; Shen et al., 2011), the deep ocean being pervasively

85 oxygenated, but with a low oxygen concentration preventing the stabilization of oxic conditions

86 in platforms throughout the Ediacaran Period (Johnston et al., 2012, 2013). Recent modeling

87 coupled with trace metal compilations further suggests that no more than $40 \%$ of the pre-NOE

88 seafloor could have been anoxic and no more than 10\% euxinic (Partin et al., 2013; Reinhard et

89 al., 2013). These models and existing data thus allow for the possibility that much of the global ocean may have been oxygenated prior to the Ediacaran Period.

91 We have applied the nitrogen isotope system to the question of the NOE because the N-isotopic

92 composition of marine sediments $\left(\delta^{15} \mathrm{~N}_{\text {sed}}\right.$; where the standard delta notation and normalization to 93 atmospheric $\mathrm{N}_{2}$ is used; Mariotti et al., 1981) is strongly dependent on the nitrogen 94 biogeochemical cycle in the water column, itself controlled by the ocean redox structure (Boyle 
et al., 2013; Canfield et al., 2010; Fennel et al., 2005; Quan and Falkowski, 2009). Although the present day nitrogen cycle is highly complex and remains poorly understood in detail (e.g. Lam et al., 2011; Sigman et al., 2009a), the current understanding of its basic features and of its isotopic imprint in the sedimentary record (Galbraith et al., 2008; Sigman et al., 2009b) have already motivated the application of $\delta^{15} \mathrm{~N}_{\text {sed }}$ to elucidate nitrogen biogeochemical cycling in past oceans. Nitrogen isotopes have been applied to the Phanerozoic (e.g. Algeo et al., 2008; Higgins et al., 2012; Junium and Arthur, 2007; Quan et al., 2008) and Precambrian records (Beaumont and Robert, 1999; Busigny et al., 2013; Garvin et al., 2009; Godfrey and Falkowski, 2009; Godfrey et al., 2013; Kump et al., 2011; Papineau et al., 2009, 2013; Stüeken, 2013; Thomazo et al., 2009, 2011) as a proxy for both ocean redox and nitrogen biogeochemistry. Here we add a new nitrogen isotope dataset from $\sim 750$ to 580 Ma strata from multiple cratons to a growing Neoproterozoic database of both bulk sedimentary $\left(\delta^{15} \mathrm{~N}_{\text {sed }}\right)$ and kerogen $\left(\delta^{15} \mathrm{~N}_{\text {ker }}\right)$ nitrogen isotope data (Cremonese et al., 2013; Kikumoto et al., 2014; Spangenberg et al., 2014) to test whether the NOE is recorded in nitrogen isotope signatures. These results show that the $\delta^{15} \mathrm{~N}_{\text {sed }}$ distributions for the Cryogenian and the Ediacaran resemble one another and that documented in the modern ocean.

\subsection{Isotope Biogeochemistry of the Nitrogen Oceanic Cycle}

Nitrogen-isotopic compositions of nitrate, particulate organic matter and surface sediments have been extensively studied to characterize the nitrogen cycle in present oceans and its transcription into the sedimentary record (Fig. 1a, e.g. Robinson et al., 2012; Somes et al., 2010; Tesdal et al., 2013; Thunell et al., 2004). Below we summarize the basic processes and pathways and associated isotope fractionation (expressed using the enrichment factor notation in $\%$, $\varepsilon_{\mathrm{a}-\mathrm{b}} \approx$ $\delta^{15} \mathrm{~N}_{\mathrm{a}}-\delta^{15} \mathrm{~N}_{\mathrm{b}}$ ) in the oceanic nitrogen cycle. 
118 The initial source of all bioavailable- $\mathrm{N}$ to the oceans is the fixation of atmospheric $\mathrm{N}_{2}\left(\mathrm{~N}_{2}\right.$ -

119 fixation) by aerobic or anaerobic autotrophs, such as cyanobacteria, which transform molecular

$120 \mathrm{~N}_{2}$ into organic matter (via $\mathrm{NH}_{4}{ }^{+}$) with a small isotope fractionation $\left(\varepsilon_{\text {org-N2 }} \sim-4\right.$ to $0 \%$; e.g.

121 Zerkle et al., 2008). Other primary photosynthetic organisms assimilate remineralized forms of

122 nitrogen mostly as $\mathrm{NO}_{3}^{-}$or $\mathrm{NH}_{4}^{+}$. The mineralization of organic matter produces $\mathrm{NH}_{4}^{+}$

123 (ammonification) with no net isotope fractionation owing to its efficiency (Möbius, 2013). If

$124 \mathrm{NH}_{4}{ }^{+}$remains stable it can then be assimilated with an isotope effect that increases strongly with

125 its availability $\left(\varepsilon_{\text {org-NH4 }} \sim 0 \%\right.$ to $-27 \%$ ) such that the organic matter can be markedly ${ }^{15} \mathrm{~N}$ -

126 depleted where $\mathrm{NH}_{4}{ }^{+}$is abundant (Pennock et al., 1996). The $\mathrm{NH}_{4}{ }^{+}$may also be oxidized. If this

127 oxidation is not complete, the residual $\mathrm{NH}_{4}{ }^{+}$will be enriched in ${ }^{15} \mathrm{~N}$, because the first oxidation

128 step to nitrite $\left(\mathrm{NO}_{2}^{-}\right)$involves a strong fractionation $\left(\varepsilon_{\mathrm{NO} 2-\mathrm{NH} 4} \sim-41 \%\right.$ to $-13 \%$; Casciotti et al.,

129 2003; Mariotti et al., 1981; Santoro and Casciotti, 2011). In oxic environments, this oxidation is

130 accomplished by nitrification (i.e. sequential oxidation to $\mathrm{NO}_{2}^{-}$and $\mathrm{NO}_{3}^{-}$) and goes to 131 completion, unless ammonium is concurrently assimilated as a nutrient. Subsequent $\mathrm{NO}_{3}{ }^{-}$

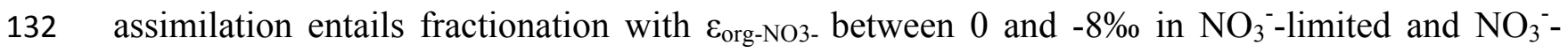

133 replete conditions, respectively (Pennock et al., 1996; Somes et al., 2010). Under dysoxic

134 conditions (i.e. typically in OMZs or within redox transition zones), $\mathrm{NO}_{3}{ }^{-}$as well as available

$135 \mathrm{NH}_{4}^{+}$and $\mathrm{NO}_{2}^{-}$are converted into gaseous species $\left(\mathrm{NO}_{2}\right.$ and/or $\left.\mathrm{N}_{2}\right)$ by an incompletely

136 understood combination of metabolic pathways that include heterotrophic denitrification and

137 anammox (anaerobic oxidation of $\mathrm{NH}_{4}^{+}$by $\mathrm{NO}_{2}^{-}$), nitrification, nitrate reduction to $\mathrm{NH}_{4}^{+}$,

138 chemolithotrophic sulfide-dependent denitrification, co-oxidation of methane and ammonium,

139 and most probably other metabolisms yet to be indentified (Lam et al., 2009, 2011; Lavik et al.,

140 2009; Mandernack et al., 2009; Wenk et al., 2013). In present day OMZs where nitrate 
141 consumption does not reach completion, the net result of these processes is a pronounced ${ }^{15} \mathrm{~N}-$ 142 enrichment in the residual $\mathrm{NO}_{3}{ }^{-}$pool (Voss et al., 2001) similar to that of the experimentally 143 determined for heterotrophic denitrification $\left(\varepsilon_{\mathrm{NO} 3-\mathrm{N} 2} \sim+15\right.$ to $+30 \%$ ) (Granger et al., 2008 ; 144 Mariotti et al., 1981). When $\mathrm{NO}_{3}{ }^{-}$consumption proceeds to completion, as in anoxic porewaters, 145 hardly any isotope effect is expressed (Lehmann et al., 2007). Finally, within stable redox 146 transition zones, nitrate (from above) and ammonium (from below) are also near-quantitatively 147 converted into $\mathrm{N}_{2}$ or $\mathrm{N}_{2} \mathrm{O}$ resulting in a discrete zone of ${ }^{15} \mathrm{~N}$-enrichment in nitrate and 148 ammonium $\left(\varepsilon_{\mathrm{NO} 3-\mathrm{N} 2} \sim+10 \% ; \varepsilon_{\mathrm{NH} 4-\mathrm{N} 2} \sim+10 \%\right)$ tied to decreasing concentrations (Fuchsman et 149 al., 2008; Thunell et al., 2004; Wenk et al., 2014).

150 The ocean's redox structure thus tightly controls the nitrogen cycle through the complex network 151 of metabolic pathways by which nitrogen flows between reservoirs. The local redox conditions 152 determine the dissolved inorganic nitrogen speciation, nitrate being stable in oxic waters and 153 ammonium in anoxic waters. The nature (i.e. OMZs versus redox transition zones), location 154 (shallow versus deep), and spatial extent of dysoxic zones determine the rate of nitrate and 155 ammonium conversion to $\mathrm{N}_{2}$ or $\mathrm{N}_{2} \mathrm{O}$, as well as their ${ }^{15} \mathrm{~N}$ enrichment.

\section{1.2. Expected $\delta^{15} N_{\text {sed }}$ signature under different ocean redox structures}

157 On continental margins and in anoxic basins, $\delta^{15} \mathrm{~N}_{\text {sed }}$ mostly records the isotopic composition of 158 primary producers, with only minor modification of (e.g. Robinson et al., 2012; Tesdal et al., 159 2013; Thunell et al., 2004). The $\delta^{15} \mathrm{~N}$ of the primary producers depends on the mass and isotope 160 balance between the two main sources of nitrogen supporting the new primary productivity, i.e. $161 \mathrm{~N}_{2}$-fixation and upwelled nitrate and/or ammonium reaching the photic zone (e.g. Somes et al., 162 2010). Because both this balance and the nitrate isotope composition are ultimately linked to the 
163 redox structure of the global ocean, $\delta^{15} \mathrm{~N}_{\text {sed }}$ should reflect this redox structure, even though its 164 isotopic signature is acquired in surface waters.

165 We review conceptual scenarios for the nitrogen cycle and $\delta^{15} \mathrm{~N}_{\text {sed }}$ expression based on two 166 ocean redox structures envisaged for the Neoproterozoic: a dominantly oxygenated ocean and a 167 redox-stratified ocean. In a dominantly oxygenated ocean (Fig. 1a), nitrate is the main form of 168 bioavailable nitrogen and it is generated by nitrification of the ammonium released by 169 remineralized organic matter. In the surface mixed layer, which broadly corresponds to the 170 euphotic zone, ammonium and nitrate are usually quantitatively reassimilated to support primary 171 productivity, without net isotope fractionation. Deeper, regenerated nitrate accumulates and 172 eventually returns to the surface ocean in upwelling zones. When the upwelling passes through 173 dysoxic or anoxic OMZs, a fraction of this nitrate pool is denitrified, increasing the $\delta^{15} \mathrm{~N}$ of 174 residual nitrate ultimately delivered to the surface. The nitrogen isotope composition of nitrate $175\left(\delta^{15} \mathrm{~N}_{\mathrm{NO3}-}\right)$ in surface waters can thus strongly vary regionally (between +1 and $+15 \%$ ) depending 176 on ocean circulation patterns and on deep and intermediate water redox condition (Somes et al., 177 2010). The $\delta^{15} \mathrm{~N}_{\text {sed }}$ distribution of present-day ocean surface sediments captures this range of 178 variation, with a mode at 5-6\%o (Fig. 2a; Tesdal et al., 2013), a small negative tail approaching $1791 \%$ and a large positive tail to $+15 \%$ corresponding to OMZs.

180 In a redox-stratified ocean (Fig $1 \mathrm{~b}$ and $\mathrm{c}$ ), the inorganic nitrogen generated by organic matter 181 mineralization will be in the form of nitrate above the redox transition zone and ammonium 182 below. The redox transition is unlikely to be stable in the surface mixed layer, owing to its rapid 183 mixing time. Thus in most locations the redox transition zone should stabilize below the surface 184 mixed layer, except possibly in up-welling zone where it may reach the surface (Kump et al., 185 2005)(Fig. 1c). In a stable situation, nitrate is depleted by assimilation in the surface mixed layer 
and accumulates below until it reaches the redox transition zone, where it is denitrified. Below the redox transition zone, ammonium accumulates. In this configuration, ammonium does not reach the surface. It is quantitatively converted to $\mathrm{N}_{2}$ or $\mathrm{N}_{2} \mathrm{O}$ within the redox transition zone by coupled nitrification-heterotrophic denitrification and anammox, as observed today in the Cariaco basin and the Black sea (Fuchsman et al., 2008; Meckler et al., 2007; Thunell et al., 2004). Overall this scenario results in extensive loss of bioavailable nitrogen (nitrate and ammonium) compared to the oxic ocean scenario. Only nitrate accumulated in between the surface mixed layer and the redox transition zone may ultimately remix into the surface ocean in upwelling zones (Fig. 1b). But this accumulation is strongly limited by down-welling zones where denitrification will occur as the nitrate crosses the redox transition zone. The amount of nitrate available for recharging the surface ocean is thus strongly controlled by the depth of the redox transition zone. The closer the redox transition zone is to the base of the surface mixed layer, the smaller the nitrate reservoir is. Resulting nitrate limitation is compensated by $\mathrm{N}_{2}$ fixation, which drives surface nitrate $\delta^{15} \mathrm{~N}$ towards $0 \%$ (Quan and Falkowski, 2009), as observed in Mediterranean sapropels and sedimentary rocks deposited during ocean anoxic events (OAEs; Fig. $2 \mathrm{~b}$ and references therein). Locally, upwelling currents may be vigorous enough for some of the ammonium to traverse the redox transition zone before being fully converted to $\mathrm{N}_{2}$ or $\mathrm{N}_{2} \mathrm{O}$. In this case, the ${ }^{15} \mathrm{~N}$-enriched residual ammonium will be assimilated either directly or after having been oxidized to nitrate, producing positive $\delta^{15} \mathrm{~N}_{\text {sed }}$ signatures similar to those found in present-day OMZs (Fig. 1b). This process has recently been proposed to explain positive $\delta^{15} \mathrm{~N}$ values on a late Paleoproterozoic platform (Godfrey et al., 2013). If the redox transition zone was shallow enough (Fig. 1c), it may impinge on the surface mixed layer in upwelling zones possibly reaching the surface (Kump et al., 2005). In this case, ammonium would be competitively 
209 assimilated by primary producers and converted to $\mathrm{N}_{2}$ or $\mathrm{N}_{2} \mathrm{O}$ by coupled nitrification210 heterotrophic denitrification and anammox. Strong upwelling would favor ammonium 211 assimilation and negative $\delta^{15} \mathrm{~N}_{\text {sed, }}$, as has been proposed to explain values as low as $-4 \%$ ouring 212 OAE2 (Higgins et al., 2012), but where conversion to $\mathrm{N}_{2}$ or $\mathrm{N}_{2} \mathrm{O}$ dominates, $\delta^{15} \mathrm{~N}_{\text {sed }}$ values 213 would trend positive (e.g., Papineau et al., 2009). Given the instability of the redox transition 214 zone in the surface mixed layer, $\delta^{15} \mathrm{~N}_{\text {sed }}$ values should be highly variable both temporally and 215 spatially, as observed in the c.a. 2.0 Ga Lower Aravalli Group (Papineau et al., 2009)(Fig. 2g).

216 The $\delta^{15} \mathrm{~N}_{\text {sed }}$ distribution of a stratified redox scenario should reflect it with high variability, 217 ranging from negative to positive values, and with a mode close to $0 \%$.

218 This brief overview highlights the difficulty of predicting $\delta^{15} \mathrm{~N}_{\text {sed }}$ signatures under non-actualistic 219 scenarios. It also demonstrates the difficulty in extrapolating results from a single basin to 220 interpreting the global nitrogen cycle given the intrinsic complexity and heterogeneity of the 221 nitrogen cycle. However, it raises the possibility that distributions of $\delta^{15} \mathrm{~N}_{\text {sed }}$ from several 222 globally distributed locations hold key information on the global nitrogen cycle. Specifically, the $223 \delta^{15} \mathrm{~N}_{\text {sed }}$ distribution in redox-stratified scenarios are expected to show a mode closer to $0 \%$ 224 (Quan and Falkowski, 2009) with marked tails toward negative and positive $\delta^{15} \mathrm{~N}_{\text {sed }}$ values in up225 welling regions. For this reason we have chosen to integrate data from multiple basins to produce 226 a global picture of $\delta^{15} \mathrm{~N}_{\text {sed }}$ spanning the purported NOE, i.e. from 750 to $580 \mathrm{Ma}$.

\section{2. Samples}

228 We present new $\delta^{15} \mathrm{~N}_{\text {sed }}$ data from four late Neoproterozoic basins that straddled the equator 229 during the Marinoan glaciation (Fig. 3): (i) the Datangpo and Doushantuo formations sampled 230 from the Yangjiaping section ( 720-580 Ma), South China; (ii) the Mirasol d'Oeste and Guia 
231 formations sampled from 4 sections spanning a cross-section of the Araras platform, Brazil; (iii)

232 the Elbobreen and Dracoisen formations sampled from a composite section ( 750-600 Ma) in 233 northeast Svalbard; (iv) and the Twitya and Sheepbed formations from a composite section 234 ( 660-600 Ma) in northwest Canada. Most samples are Ediacaran (635-541 Ma) in age, such 235 that this data set spans the first fossil evidence of bilaterians ( $575 \mathrm{Ma}$; Narbonne and Gehling, 236 2003) and record what is commonly regarded as a transition from dominantly anoxic to 237 oxygenated oceans (Fike et al., 2006; Sahoo et al., 2012). A small subset of older samples 238 extends the record beyond the Cryogenian (c.a. 720-635 Ma) glaciations. A description of 239 geological backgrounds for the sampled sections is included in the supplementary material. We 240 only summarize below the depositional depth and redox conditions inferred for each of these 241 sections.

242 In the Yangtze platform (South China) sections, iron speciation, trace metal contents, sulfur and 243 carbon isotopes, and pyrite morphologies indicate that the water column was redox stratified 244 during the deposition of both the Datangpo and Doushantuo formations (Ader et al., 2009; 245 McFadden et al., 2007; Li et al., 2010; Li et al., 2012; Wang et al., 2012). However, enrichment 246 of Mo in Doushantuo shales indicates that a significant percentage of the open ocean must have 247 been oxygenated at the time (Sahoo et al., 2012). At Yangjiaping, both formations were probably 248 deposited in oxic shallow waters (Ader et al., 2009; Li et al., 2012; Wang et al., 2012), while at 249 the Wuhe section, for which previous $\delta^{15} \mathrm{~N}_{\text {sed }}$ results are available (Kikumoto et al., 2014), the 250 Doushantuo Formation was deposited in a deep anoxic inner-shelf environment.

251 On the Araras platform, the four studied sections span a platform transect (Fig. S1) in an overall 252 deepening upward succession: the lower Mirassol d'Oeste Formation was deposited in shallow 253 water and overlying Guia Formation was deposited in increasingly deeper environments, with 
254 the upper part of the unit deposited in a slope setting. The trace metal contents in the same

255 samples for which $\delta^{15} \mathrm{~N}_{\text {sed }}$ have been obtained indicate a fully oxygenated water column, with 256 possible episodes of porewater anoxia approaching the sediment-water interface on the slope 257 (Sansjofre et al., 2014).

258 Shales from Svalbard and Canada were all deposited below storm wave base. For the Elbobreen 259 and Dracoisen formations (Northeast Svalbard) Fe/Al data lie close to the local detrital baseline 260 of 0.58 with a few values above but most lying below (Table S1 in supplementary material). 261 These results are not conclusive, but are consistent with liberation of iron from ferrouginous $262 \mathrm{OMZs}(\mathrm{Fe} / \mathrm{Al}<0.58)$ and subsequent addition to more oxygenated parts of the water column, as 263 occurs in modern OMZs (Scholz et al., 2014). We have no direct constraints on the depositional 264 redox conditions of our samples from the Twitya and Sheepbed formations (Northwest Canada). 265 However, iron speciation data are available for correlative sections of the lower Sheepbed 266 Formation (Johnston et al., 2013; Shen et al., 2008). These data were interpreted to indicate 267 anoxic and ferruginous deep waters with variations in the redox transition zone depth, such that 268 the depositional environment may have been oxic in some locations. We note, however, that $269 \mathrm{FeHR} / \mathrm{FeT}$ data lie close to the 0.38 threshold used to discriminate anoxic from oxic 270 environments and the FeT/Al ratio are close to both the generic detrital ratio of 0.53 (Johnston et 271 al., 2013), which means the data do not conclusively demonstrate anoxic conditions. As for 272 Svalbard, it is possible that ferruginous conditions were confined to an $\mathrm{OMZ}$ in an otherwise 273 oxygenated ocean. 
275 Samples were ground in an agate mortar and sieved to ensure a grain size $<140 \mu \mathrm{m}$. To 276 concentrate nitrogen in the insoluble residue, most carbonate-rich samples were first 277 decarbonated in $\mathrm{HCl} 6 \mathrm{~N}$ overnight at room temperature, followed by $2 \mathrm{~h}$ at $80^{\circ} \mathrm{C}$. Residues were 278 washed with distilled water, centrifuged and dried at $50^{\circ} \mathrm{C}$. When enough material was available 279 and N-content was above $200 \mathrm{ppm}$, samples were prepared by conventional sealed tube 280 combustion to convert total nitrogen to $\mathrm{N}_{2}$ (Dumas combustion). This method is hereafter 281 referred to as the conventional method (see Ader et al. (1998) for a detailed description). The $\mathrm{N}_{2}$ 282 was then measured on a dual inlet Thermo Finnigan Delta+XP mass spectrometer allowing 283 analyses on as low as 2 micromoles $\mathrm{N}_{2}$ with a precision of $\pm 0.2 \%(1 \sigma)$. Nitrogen blanks were 284 approximately 0.15 micromole, thus representing less than $10 \%$ of the measured nitrogen on the 285 least $\mathrm{N}$-rich samples. The reproducibility of the $\delta^{15} \mathrm{~N}_{\text {sed }}$ measurements was $\pm 0.2 \%$ ( $\left.1 \sigma\right)$.

286 For samples containing a limited amount of material, N-isotope analyses were performed using 287 sealed-tube combustion and on-line $\mathrm{N}_{2}$ purification on an ultra-high vacuum line with direct 288 introduction to a static mass spectrometer (hereafter referred to as the static method) following 289 an established protocol (Ader et al., 2006; Busigny et al., 2003, 2005; Thomazo et al., 2011). 290 Powdered samples (between 5 and $30 \mathrm{mg}$ ) were embedded in a platinum parcel, then evacuated 291 under vacuum at $150^{\circ} \mathrm{C}$ before being sealed in an evacuated and pre-purified quartz tube with an 292 excess of $\mathrm{CuO}$ and $\mathrm{Cu}$ wire and $\mathrm{CaO}$ granules. The sample was combusted at $950{ }^{\circ} \mathrm{C}$ for $6 \mathrm{~h}$ and 293 the resulting $\mathrm{N}_{2}$ purified and quantified on an ultra-high vacuum line directly coupled to our 294 static mass spectrometer. Precision for $\delta^{15} \mathrm{~N}$ via this method is $\pm 0.3 \%$ o $(1 \sigma)$ based on repeat 295 analyses. Blanks yielded $\delta^{15} \mathrm{~N}$ values of $+1.5 \pm 3 \%$ and higher nitrogen amounts $(\sim 30 \mathrm{ng})$ than 296 expected based on prior work in our lab (Ader et al., 2006; Busigny et al., 2005; Thomazo et al., 297 2011), which is likely a result of the lower sample degassing temperature set at $150^{\circ} \mathrm{C}$ to avoid 
298 nitrogen devolatilisation, the thermal maturation experienced by our samples being lower than 299 greenschist facies. In most cases this blank content accounts for less than 3\% of the total 300 nitrogen, but reached $10 \%$ in some of the most nitrogen-poor samples. All results are blank301 corrected and given in standard $\delta$ notation, calibrated to Air (Mariotti et al., 1981).

302 In order to ascertain whether bulk and decarbonated samples, as well as conventional and static 303 methods, yield comparable results, selected samples were analyzed by multiple methods (Table $304 \mathrm{~S} 2$ ). $\delta^{15} \mathrm{~N}_{\text {sed }}$ results obtained on bulk and decarbonated samples using the conventional or the 305 static method compare well given the reproducibility of each method. When all data are 306 considered together, the $\delta^{15} \mathrm{~N}_{\text {sed }}$ reproducibility $(1 \sigma)$ is usually better than $\pm 0.35 \%$, and always 307 better than $\pm 0.63 \%$. N-contents also compare quite well between methods, except for pure 308 carbonate samples, for which bulk N-contents measured on the decarbonated residue are often 309 lower than those measured directly on bulk samples. It is likely that a significant fraction of the 310 very small residue was lost during the decarbonation step, probably as a supernatant during 311 rinsing and centrifugation. Therefore, $\mathrm{N}$-contents determined using the decarbonated residue of 312 carbonate samples are probably slightly underestimated.

\section{4. Results}

314 Our $\delta^{15} \mathrm{~N}_{\text {sed }}$ results are listed in the supplementary information Table S3 and presented as 315 chemostratigraphic profiles (together with available $\delta^{13} \mathrm{C}_{\text {org }}$ and $\delta^{13} \mathrm{C}_{\text {carb }}$ data) for each of the 316 studied sections in Figure 4. For the Araras platform $(n=41), \delta^{15} \mathrm{~N}_{\text {sed }}$ data have been obtained 317 from 4 sections spanning the platform (Fig. 4a-c). $\delta^{15} \mathrm{~N}_{\text {sed }}$ data for the shallow-water cap 318 dolostone of the Mirassol d'Oeste Formation (directly overlying the Marinoan glacial deposits) 319 are only available in the Terconi-Camil composite section. They show the largest distribution 
320 with $\delta^{15} \mathrm{~N}_{\text {sed }}$ values ranging from +2 to $+10 \%$ (Fig. $4 \mathrm{a}$ ). $\delta^{15} \mathrm{~N}_{\text {sed }}$ data for the overlying Guia 321 Formation are available for all three sections (Fig. $4 a-c)$. They lie between +2 and $+6 \%$, and no 322 systematic variation is apparent either temporally or between sections.

323 For South China, all samples come from the Yangjkiaping section (Fig. 4d). In the Datangpo 324 Formation, $\delta^{15} \mathrm{~N}_{\text {sed }}$ data cluster around $+4 \%$. In the Doushantuo Formation, $\delta^{15} \mathrm{~N}_{\text {sed }}$ values 325 increase within the 4 meter-thick cap carbonate from $+3 \%$ up to $+5.5 \%$, at which they remain 326 through the subsequent $40 \mathrm{~m}$. Above, $\delta^{15} \mathrm{~N}_{\text {sed }}$ values are more variable, but overall decrease to $327+2.5 \%$ in the lower Dengying Formation. Recently published $\delta^{15} \mathrm{~N}_{\text {sed }}$ data from the Doushantuo 328 Formation from a drill-core in the Three Gorges area that penetrates a deep inner-shelf setting on 329 the Yangtze platform (Kikumoto et al., 2014) show similar $\delta^{15} \mathrm{~N}_{\text {sed }}$ values than the Yangjiaping 330 section, which correspond to the shelf margin (Fig. 2c). Both sections also display similar $\delta^{15} \mathrm{~N}_{\text {sed }}$ 331 stratigraphic variations (Fig. 4d, this study and Fig. 2, Kikumoto et al., 2014) in spite of the 332 different depositional setting, lithologies and $\delta^{13} \mathrm{C}_{\mathrm{org}}$ and $\delta^{13} \mathrm{C}_{\text {carb }}$ stratigraphic variations. 333 Samples from Svalbard $(n=18)$ present very homogeneous $\delta^{15} \mathrm{~N}_{\text {sed }}$ values ranging from +4.1 to $334+6.3 \%$ o (Fig. 4e), although data from the post-Marinoan Dracoisen Formation show a distinct 335 positive upward trend from +4 to $+5.5 \%$ (Fig. $4 \mathrm{e}$ ). All samples from northwest Canada ( $\mathrm{n}=8$ ) 336 fall between +2 and $4 \%$ (Fig. 4f). No obvious correlation with $\delta^{13} \mathrm{C}_{\text {org }}$ and $\delta^{13} \mathrm{C}_{\text {carb }}$ is evident in 337 any of the sections (Fig. 4 and Fig. 5d).

338 These results are synthesized in histograms in Figure 2 together with $\delta^{15} \mathrm{~N}_{\text {sed }}$ data previously 339 published for the Doushantuo and Dengying formations, South China (Cremonese et al., 2013;) 340 and $\delta^{15} \mathrm{~N}_{\text {kerogen }}$ data from the Tamengo Formation, Brazil (Kikumoto et al., 2014; Spangenberg et 341 al., 2014). $\delta^{15} \mathrm{~N}_{\text {sed }}$ values for South China range between +2.2 and $+8.5 \%$ (Fig. 2c); for the 342 Amazonian craton between +2.2 and $+10.5 \%$; for the Late Ediacaran Tamengo Formation 
343 between -3.3 and $+3.1 \%$, defining the lower end of the distribution (Fig. $2 \mathrm{~d}$ ); for northwestern 344 Canada between +2 and $+4 \%$ and for Svalbard between +4 and $+7 \%$ (Fig. 2e). Overall, the $\delta^{15} \mathrm{~N}$ 345 values $(n=158)$ range from -3.3 to $+10.5 \%$, with roughly $40 \%$ of the data falling between +3 346 and $+6 \%$ (Fig. $2 \mathrm{f}$ ). No time-based evolution is evident from the comparison of the Cryogenian 347 values to those of the Ediacaran (Fig. 2f).

\section{Discussion}

\subsection{Preservation of the $\delta^{15} N_{\text {sed }}$ signature}

350

351

In sediments from continental margins and anoxic depositional settings, $\delta^{15} \mathrm{~N}$ of primary producers is recorded with only minor modification in $\delta^{15} \mathrm{~N}_{\text {sed }}$ in spite of the early diagenetic remineralization of organic matter and ammonium fixation in clay minerals (e.g. reviews in Robinson et al., 2012; Thomazo et al., 2011). The conservation of primary signatures is illustrated in sediments from the eastern Mediterranean sapropels and the OAE2 event in the proto-North Atlantic by the similarity between $\delta^{15} \mathrm{~N}_{\text {sed, }}, \delta^{15} \mathrm{~N}_{\text {kerogen }}$ and $\delta^{15} \mathrm{~N}$ of primary producers as reconstructed from porphyrin $\delta^{15} \mathrm{~N}$ (Higgins et al., 2010; 2012). However, most Precambrian sedimentary rocks have experienced some degree of post-depositional $\delta^{15} \mathrm{~N}_{\text {sed }}$ modification. Devolatilization of fixed ammonium during metamorphism has been identified as the main culprit. At metamorphic grades higher than greenschist facies, a decrease in $\mathrm{N}$ content is often coupled to an increase in $\delta^{15} \mathrm{~N}_{\text {sed }}$ as ${ }^{15} \mathrm{~N}$-depleted fixed ammonium is preferentially volatilized (Bebout and Fogel, 1992; Busigny et al., 2003; Jia and Kerrich 2004; Jia, 2006; Mingram and Brauer 2001; Pinti et al., 2009; Yui et al., 2009). The reliability of $\delta^{15} \mathrm{~N}_{\text {sed }}$ in Precambrian sedimentary rocks as a tracer for initial $\delta^{15} \mathrm{~N}$ of primary producers thus remains controversial. This problem has been addressed by comparing $\delta^{15} \mathrm{~N}_{\text {sed }}$ and $\delta^{15} \mathrm{~N}_{\text {kerogen }}$ data from the same 
365 successions (Godfrey et al., 2009, 2013; Kump et al., 2011), on the basis that $\delta^{15} \mathrm{~N}_{\text {kerogen }}$ should 366 not be modified by metamorphism (Ader et al., 1998, 2006; Boudou et al., 2008). So far, these 367 comparisons have shown mixed results: two successions show $\delta^{15} \mathrm{~N}_{\text {sed }}$ to be higher than

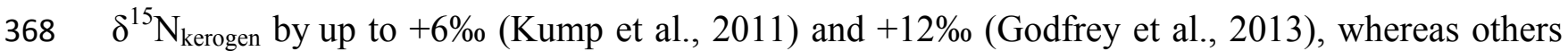

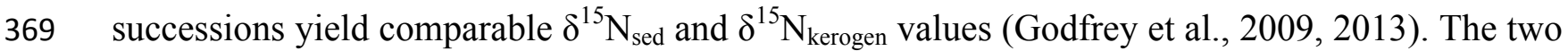
370 successions with higher $\delta^{15} \mathrm{~N}_{\text {sed }}$ than $\delta^{15} \mathrm{~N}_{\text {kerogen }}$ are recognized as having undergone lower 371 greenschist facies (Kump et al., 2011) or higher (Godfrey et al., 2013) peak metamorphic 372 conditions. Peak metamorphic temperatures for the other successions are not reported. These 373 mixed results raise the specter of overprinting of $\delta^{15} \mathrm{~N}_{\text {sed }}$ by devolatilization and/or of 374 overprinting of $\delta^{15} \mathrm{~N}_{\text {kerogen }}$ by $\mathrm{N}$-contamination during the HF extraction of $\mathrm{N}$-poor kerogen (Ader 375 et al., 2006) in rocks metamorphosed to greenschist or higher facies. They nevertheless suggest 376 that $\delta^{15} \mathrm{~N}_{\text {sed }}$ may be preserved in rocks that have experienced minimal metamorphism.

377 In any case, for this study the maximum metamorphic conditions for the studied locations were 378 below greenschist facies (Supplementary material), minimizing the risk of post-depositional 379 modification of the $\delta^{15} \mathrm{~N}_{\text {sed }}$ signal. $\mathrm{N} / \mathrm{C}$ ratios strongly vary (Fig. 5b), but the $\mathrm{N}$ and TOC contents 380 of decarbonated samples show a rough correlation (Fig. 5c), suggesting $\mathrm{N}$ originates from the 381 organic carbon matter. The fact that $\delta^{15} \mathrm{~N}_{\text {sed }}$ does not correlate with either $\mathrm{N}_{\text {decarb }}$ content (Fig. 5a) 382 or $\mathrm{C} / \mathrm{N}$ ratio (Fig. 5b) suggests that even if some nitrogen was redistributed between organic 383 matter, clay minerals and fluid phases during diagenesis and low-grade metamorphism, bulk $384 \delta^{15} \mathrm{~N}_{\text {sed }}$ values should not have been significantly modified. Finally, it would be very unlikely for 385 burial and metamorphic processes to have resulted in the observed similarities in $\delta^{15} \mathrm{~N}_{\text {sed }}$ values 386 across all studied locations, as well as across transects of the Araras and Yangtze platforms, in 
387 spite of the variable lithologies and thermal histories. We thus proceed on the assumption that

$388 \quad \delta^{15} \mathrm{~N}_{\text {sed }}$ values reflect primary biomass signatures.

3895.2 Significance of $\delta^{15} N_{\text {sed }}$ in the context of global ocean redox structure

390 The distribution of $\delta^{15} \mathrm{~N}_{\text {sed }}$ in analyzed Neoproterozoic rocks (mode of $\sim+4 \%$, Fig. 2c) is clearly 391 more like that of modern sediments (mode of $\sim+5 \%$, Fig. 2 a) than to that of OAEs (mode of $3921 \%$, Fig. 2b). The fact that most $\delta^{15} \mathrm{~N}_{\text {sed }}$ values do not cluster in the -4 to $+2 \%$ range typical of 393 OAEs, which have been consistently interpreted as representing episodes of redox stratification, 394 indicates that during most of the studied time interval, the nitrogen cycle and ocean redox 395 structure differed from that of a redox-stratified ocean. The Neoproterozoic $\delta^{15} \mathrm{~N}_{\text {sed }}$ distribution 396 with a mode close to $+4 \%$ would be compatible with redox-stratified ocean only if all studied 397 sections (except that of the Rio de la Plata craton with $\delta^{15} \mathrm{~N}_{\mathrm{ker}}$ close to $0 \%$ ) were located in the 398 vicinity of upwelling zones, which would be an extraordinary coincidence. Consequently, a 399 globally redox-stratified ocean is an unlikely scenario to explain the Cryogenian-Ediacaran $400 \quad \delta^{15} \mathrm{~N}_{\text {sed }}$ distribution.

401 In contrast, the $\delta^{15} \mathrm{~N}$ distribution for the $\sim 750$ to $580 \mathrm{Ma}$ period, while being markedly different 402 from that of OAEs, is strikingly similar to that of modern sediments (Fig. 2a). The most 403 parsimonious hypothesis is thus that it reflects a nitrogen cycle similar to the one operating in the 404 modern ocean, where nitrate was stable throughout the ocean, except in anoxic OMZs and 405 locally restricted anoxic basins. It implies that most of the late Neoproterozoic oceans contained 406 enough dissolved $\mathrm{O}_{2}$ to stabilize nitrate, with the probable exception of transient OAEs. This 407 interpretation is compatible with the existing knowledge of the redox depositional conditions for 408 the studied samples. Samples from the Araras platform (Amazonian craton) show oxic 
409 depositional conditions (Sansjofre et al., 2014), while available data for Svalbard and Canada

410 sections are compatible with deposition under oxygenated conditions or within anoxic OMZs in

411 an otherwise oxygenated ocean. The Datangpo and Doushantuo formations (South China) were

412 both deposited from a redox-stratified water column ( $\mathrm{Li}$ et al. 2010; Li et a., 2012), yet their

$413 \delta^{15} \mathrm{~N}_{\text {sed }}$ values in both shelf margin and inner-shelf basin settings are positive and lie in the same

414 range as the other locations. These patterns are fully compatible with nitrate having being

415 supplied to these areas through surface currents in a scenario analogous to the present-day anoxic

416 Cariaco Basin, where $\delta^{15} \mathrm{~N}_{\text {sed }}$ values of $\sim+3.5 \%$ are maintained (Thunell et al., 2004). The $\delta^{15} \mathrm{~N}_{\text {sed }}$

417 distribution compiled from these locations is thus highly likely to record the $\delta^{15} \mathrm{~N}$ distribution of

418 the global ocean nitrate inventory, albeit with minor regional influences. As to the negative tail

419 of the distribution defined by samples from the Tamengo Formation deposited in an anoxic basin

420 (Spangenberg et al., 2014), it records the regional signal of $\mathrm{N}_{2}$-fixation and/or ammonium

421 assimilation expected in the case of redox stratification (Junium and Arthur 2007; Higgins et al.,

422 2012).

423 In detail, the $\delta^{15} \mathrm{~N}$ distribution for the $\sim 750$ to 580 Ma period shows minor differences with the

424 modern distribution. While these differences may simply reflect sampling bias, they may also

425 speak to important differences in the global ocean redox structure, which we explore here.

426 Compared to the modern $\delta^{15} \mathrm{~N}$ distribution, that of the $\sim 750$ to $580 \mathrm{Ma}$ is slightly shifted towards

427 lower $\delta^{15} \mathrm{~N}_{\text {sed }}$ values, its positive tail is less prominent, and its negative tail extends to lower

428 values (as low as $-3.3 \%$; Figs. 2,7 ). Its mode is also $1 \%$ lower than that of modern sediments.

429 This shift to lower $\delta^{15} \mathrm{~N}_{\text {sed }}$ values is compatible with the hypothesis of an oxygenated ocean, but 430 one containing less dissolved oxygen than the modern ocean. Restricted anoxic basins would be 431 more common, increasing the proportion of $\delta^{15} \mathrm{~N}_{\text {sed }}$ values close to $0 \%$. Similarly, OMZs would 
432 be more widespread and severe, possibly reaching euxinia, which would have resulted in more 433 common quantitative denitrification, hence driving $\mathrm{N}_{2}$-fixation. $\mathrm{O}_{2}$ penetration in sediments 434 would also have been less compared to the modern ocean, increasing the surface of sediments 435 experiencing conditions favorable to quantitative sedimentary denitrification. Combined, these 436 effects would have decreased the nitrate inventory of the ocean without significantly increasing 437 residual nitrate $\delta^{15} \mathrm{~N}$ values, driving $\mathrm{N}_{2}$-fixation to compensate for the nitrate loss and hence 438 decreasing $\delta^{15} \mathrm{~N}$ of the global nitrate inventory. Importantly, the absence of marked change in $439 \delta^{15} \mathrm{~N}$ signatures during the latter half of the Neoproterozoic (Fig. 4 and Fig. 2f) implies no 440 fundamental and irreversible change in the nitrogen cycle during this interval. These data imply 441 no first order change in oceans redox structure across the NOE and by extension, suggest that 442 pervasive oxygenation of the oceans occurred before $750 \mathrm{Ma}$.

443 Few $\delta^{15} \mathrm{~N}$ data are available for the early Neoproterozoic and late Mesoproterozoic, but 444 significant data have recently been published for the early Mesoproterozoic and Paleoproterozoic 445 ( 2.1 to 1.4 Ma; Busigny et al., 2013; Kump et al., 2011; Papineau et al., 2009, 2013; Stüeken, 446 2013). These data are synthetized in Figure $2 \mathrm{~g}$. The mode of the $2.1-1.4 \mathrm{Ga} \delta^{15} \mathrm{~N}$ distribution is 447 closer to $+2 \%$ compared with $+4 \%$ or for the $\sim 750$ to 580 Ma period, but is clearly distinct from 448 the $-1 \%$ mode characteristic of the Phanerozoic OAEs. The offset to lower $\delta^{15} \mathrm{~N}$ values can be 449 interpreted along the same lines of reasoning as above-increased area of restricted anoxic 450 basins and euxinic OMZs, along with less pervasive $\mathrm{O}_{2}$ penetration in sediments overlain by an 451 oxygenated water column. Redox-stratified restricted basins and OMZs on continental platforms 452 were likely more numerous than during the Neoproterozoic. The extremely large range of $\delta^{15} \mathrm{~N}$ 453 (from -4 up to $+24 \%$ ) identified in the Arivilli group (India) may indeed correspond to a 454 restricted anoxic basin or an euxinic OMZ, where the positive $\delta^{15} \mathrm{~N}$ reflects impingement of the 
455 redox transition zone on the surface mixed layer (Papineau et al., 2009, 2013). This interpretation

456 implies a similar N-cycle than in the modern ocean with nitrate being stable in most of the ocean.

457 It is at odds with most previous interpretations of Proterozoic N-cycling which are predicated on

458 the assumption of a redox-stratified ocean. However, recent interpretations of trace metal 459 compilations suggest that a minimum of $60 \%$ of the seafloor was overlain by oxygenated waters

460 in the Proterozoic (Partin et al., 2013; Reinhard et al., 2013). This significant revision allows for 461 the possibility that the $\delta^{15} \mathrm{~N}$ distribution for the $2.1-1.4$ Ga period may reflect a modern style N462 cycle in pervasively oxygenated oceans.

463 It is difficult to place a quantitative constraint on the dissolved $\mathrm{O}_{2}$ concentration of Proterozoic 464 oceans given our poor knowledge of the $\mathrm{O}_{2}$ abundance required to stabilize nitrate. 465 Measurements performed using the recently developed highly sensitive STOX oxygen sensors 466 show that the accumulation of $\mathrm{NO}_{2}^{-}$, the intermediate compound associated with $\mathrm{N}-$ loss in 467 OMZs, is restricted to $\mathrm{O}_{2}$ concentrations lower than $50 \mathrm{nM}$ (Thamdrup et al., 2012). A 468 conservative lower estimate for $\mathrm{O}_{2}$ concentration in a significant part of the oceans between 740 469 and $580 \mathrm{Ma}$ can thus be fixed at $50 \mathrm{nM}$. However, this is probably underestimated by at least two 470 orders of magnitude, considering that the activity of metabolic pathways controlling N-losses in 471 OMZs have been detected at $\mathrm{O}_{2}$ concentrations as high as $20 \mu \mathrm{M}$ (Kalvelage et al., 2011), which 472 prevent $\mathrm{NO}_{2}^{-}$accumulation. In any case, the widespread stability of nitrate implies that the 473 Cryogenian and Ediacaran oceans were neither dominantly ferruginous nor sulfidic, because 474 nitrate would have been reduced by ferrous iron or sulfide microbial oxidation, respectively 475 (Canfield et al., 2010; Lavik et al., 2009; Pantke et al., 2012; Weber et al., 2006). Apart from 476 possible episodic OAEs, anoxic waters (ferruginous or sulfidic) must therefore have been 477 restricted to intracratonic and silled basins, zones of widespread upwelling on open continental 
478 shelves, and probably to a thin layer of bottom water overlying the sediment-water interface (Fig.

479 1d).

481 A host of redox proxy datasets have been published recently for the Neoproterozoic and early 482 Cambrian with seemingly contradictory implications. Compilations of trace metal data from 483 euxinic black shales through time broadly indicate a major oxygenation event sometime in the 484 late Neoproterozoic: the NOE (Fig. 6; Partin et al., 2013; Och and Shields-Zhou, 2012; Scott et 485 al., 2008). Canfield et al. (2007) argued more specifically that deep ocean oxygenation occurred 486 in the middle Ediacaran Period based on a compilation of iron speciation data from the Ediacaran 487 succession of southeast Newfoundland. On the other hand, high-resolution trace metal 488 abundance datasets from the organic-rich Doushantuo Formation in from South China show a 489 prominent spike in Mo, V, and U in the early Ediacaran Period, which imply ocean oxygenation 490 occurred shortly after the Marinoan (end-Cryogenian) glaciation (Sahoo et al., 2012). Other data 491 sets from individual basins variably imply oxic, anoxic, and euxinic continental shelves during 492 the Ediacaran (Johnston et al., 2012, 2013; Li et al., 2010; Sansjofre et al., 2014), while studies 493 of the Precambrian-Cambrian boundary interval indicate ocean anoxia in the late Ediacaran494 early Cambrian (Kimura et al., 1997; Schröder and Grotzinger, 2007). Do these seemingly 495 contradictory ocean redox datasets imply that the samples or proxies are unreliable or can these 496 data be reconciled with a single model for Neoproterozoic oxygenation?

497 We argue for the latter based on the $\delta^{15} \mathrm{~N}_{\text {sed }}$ record. The most parsimonious explanation for the 498 similarity of the $\delta^{15} \mathrm{~N}_{\text {sed }}$ distribution for the 750-580 Ma period to that of modern sediments is 499 that nitrate was largely stable in the Neoproterozoic ocean by $\sim 750 \mathrm{Ma}$, and hence that the 
500

501

502

503

504

505

506

507

508

509

510

511

512 towards water column anoxia.

513 Our interpretation is compatible with the latest reinterpretation of trace metal data, recognized 514 proxies for the global ocean redox (Algeo and Rowe, 2011). Reinhard et al. (2013) used a simple

515 mass balance model to show that the low trace metal abundances in black shales prior to $630 \mathrm{Ma}$

516 allow for a minimum of $60 \%$ of the seafloor to have been oxygenated throughout the

517 Proterozoic. Given that the degree to which anoxia and/or euxinia extended into the water

518 column from the seafloor remains completely unconstrained, anoxia may even have been

519 restricted to microbial matts covering the sediment-water interface (Pawlowska et al., 2013) or to

520 a thin layer of bottom water, leaving most of the water column oxygenated enough to allow

521 nitrate accumulation (Fig. 1d). Therefore the unambiguous shift in trace metal abundance at 630

522 Ma (Och and Shields-Zhou, 2012; Partin et al., 2013; Reinhard et al., 2013; Sahoo et al., 2012), 
523 rather than heralding deep ocean oxygenation, may instead only record an increase in

524 atmospheric $\mathrm{O}_{2}$, and hence dissolved $\mathrm{O}_{2}$, beyond a critical threshold, thereby increasing the

525 penetration depth of $\mathrm{O}_{2}$ within seafloor sediments and hence total surface area of oxygenated

526 seafloor on continental shelves. This may have been the threshold that permitted the earliest

527 animals to evolve or develop more energy intensive metabolisms, such as burrowing and

528 predation (Sperling et al., 2013).

\section{6. Conclusions}

530 The $\delta^{15} \mathrm{~N}_{\text {sed }}$ datasets presented here (Fig. 2, 4 and 6) suggests that the global nitrogen cycle 531 operated similarly in the second half of the Neoproterozoic Era to in the modern ocean. If true, 532 then it implies that nitrate was stable in the latter Neoproterozoic ocean, which, by extension, 533 was at least mildly oxygenated. This conclusion is compatible with recent modeling of trace 534 element data that suggest that most of the global Proterozoic ocean was sufficiently oxygenated 535 to also accumulate trace metals (Partin et al., 2013; Reinhard et al., 2013). Although this 536 hypothesis does not discount a possible rise in atmospheric and oceanic oxygen levels during this 537 period or significant fluctuations associated with snowball glaciations, it does suggest that the 538 major transition from a dominantly anoxic to oxygenated deep-ocean did not happen between $539 \sim 750$ and $580 \mathrm{Ma}$ but rather sometime prior to $750 \mathrm{Ma}$, and perhaps much earlier in the 540 Proterozoic.

\section{Acknowledgments}

542 The project was supported by a French MRT doctoral fellowship and a SETSI grant to PS; two 543 INSU (SYSTER) grants as well as an Emergence grant from Paris council (PI Magali Bonifacie)

544 to MA and PS. RIFT and ACRN were supported by the INCT-Geociam program, and by 
FAPESP and CNPq grants. GPH acknowledges donors of the American Chemical Society Petroleum Research Fund for partial support of this research. GPH benefited from two month of invitation to stay at IPGP. This is IPGP contribution XX.

\section{References}

Ader, M., Boudou, J.-P., Javoy, M., Goffe, B., Daniels, E., 1998. Isotope study on organic nitrogen of Westphalian anthracites from the Western Middle field of Pennsylvania (U.S.A.) and from the Bramsche Massif (Germany). Organic Geochemistry 29, 315-323.

Ader, M., Cartigny, P., Boudou, J.-P., Oh, J.-H., Petit, E., Javoy, M., 2006. Nitrogen isotopic evolution of carbonaceous matter during metamorphism: Methodology and preliminary results. Chemical Geology 232, 152-169.

Ader, M., Macouin, M., Trindade, R.I.F., Hadrien, M.H., Yang, Z., Sun, Z., Besse, J., 2009. A multilayered water column in the Ediacaran Yangtze platform? Insights from carbonate and organic matter paired $\delta^{13} \mathrm{C}$. Earth and Planetary Science Letters 288, 213-227.

Algeo, T., Rowe, H., Hower, J.C., Schwark, L., Herrmann, A., Heckel, P., 2008. Changes in ocean denitrification during Late Carboniferous glacial-interglacial cycles. Nature geoscience 1, 709-714.

Algeo, T., Rowe, H., 2012 Paleoceanographic applications of trace-metal concentration data. Chemical Geology 324-325, 6-18.

Arnaboldi, M., Meyers, P.A., 2006. Patterns of organic carbon and nitrogen isotopic compositions of latest Pliocene sapropels from six locations across the Mediterranean Sea. Palaeogeography, Palaeoclimatology, Palaeoecology 235, 149-167.

Beaumont, V., Robert, F., 1999. Nitrogen isotope ratios of kerogens in Precambrian cherts: a record of the evolution of atmosphere chemistry? Precambrian Research 96, 63-82.

Bebout, G.E., Fogel, M.L., 1992. Nitrogen-isotope compositions of metasedimentary rocks in the Catalina Schist, California: Implications for metamorphic devolatilization history. Geochimica et Cosmochimica Acta 56, 2839-2849.

Boudou, J.-P., Schimmelmann, A., Ader, M., Mastalerz, M., Sebilo, M., Gengembre, L., 2008. Organic nitrogen chemistry during low-grade metamorphism. Geochimica et Cosmochimica Acta 72, 1199-1221.

Boyle, R.A., Clark, J.R., Poulton, S.W., Shields-Zhou, G., Canfield, D.E., Lenton, T.M., 2013. Nitrogen cycle feedbacks as a control on euxinia in the mid-Proterozoic ocean. Nature Communication 4, 1533.

Busigny, V., Cartigny, P., Philippot, P., Ader M., Javoy, M., 2003. Massive recycling of nitrogen and other fluid-mobile elements $(\mathrm{K}, \mathrm{Rb}, \mathrm{Cs}, \mathrm{H})$ in a cold slab environment: evidences from $\mathrm{HP}$ to 
UHP oceanic metasediments of the Schistes Lustrés nappe (Western Alps, Europe). Earth and Planetary Science Letters 215, 27-42.

Busigny, V., Ader, M., Cartigny, P., 2005. Quantification and isotopic analysis of nitrogen in rocks at the ppm level using sealed tube combustion technique: A prelude to the study of altered oceanic crust. Chemical Geology 223, 249-258.

Busigny, V., Lebeau, O., Ader, M., Krapez, B., Bekker, A., 2013. Nitrogen cycle in the Late Archean ferruginous ocean. Chemical Geology 362, 115-130.

Butterfield, N.J. 2009. Oxygen, animals and oceanic ventilation: an alternative view. Geobiology 7, 1-7.

Calvert, S.E., Bustin, R.M., Ingall, E.D., 1996. Influence of water column anoxia and sediment supply on the burial and preservation of organic carbon in marine shales. Geochimica et Cosmochimica Acta 60, 1577-1593.

Canfield, D.E., Glazer, A.N., Falkowski, P.G., 2010. The Evolution and Future of Earth's Nitrogen Cycle. Science 330, 192-196.

Canfield, D.E., Poulton, S.W., Knoll, A.H., Narbonne, G.M., Ross, G., Goldberg, T., Strauss, H., 2008. Ferruginous Conditions Dominated Later Neoproterozoic Deep-Water Chemistry. Science $321,949-952$.

Canfield, D.E., Poulton, S.W., Narbonne, G.M., 2007. Late-Neoproterozoic Deep-Ocean Oxygenation and the Rise of Animal Life. Science 315, 92-94.

Cao, C., Love, G.D., Hays, L.E., Wang, W., Shen, S., Summons, R.E., 2009. Biogeochemical evidence for euxinic oceans and ecological disturbance presaging the end-Permian mass extinction event. Earth and Planetary Science Letters 281, 188-201.

Casciotti, K.L., Sigman, D.M., Ward, B.B., 2003. Linking Diversity and Stable Isotope Fractionation in Ammonia-Oxidizing Bacteria. Geomicrobiology Journal 20, 335-353.

Close, H.G., Bovee, R., Pearson, A., 2011. Inverse carbon isotope patterns of lipids and kerogen record heterogeneous primary biomass. Geobiology, 9, 250-265.

Cremonese, L., Shields-Zhou, G., Struck, U., Ling, H.-F., Och, L., Chen, X., Li, D., 2013. Marine biogeochemical cycling during the early Cambrian constrained by a nitrogen and organic carbon isotope study of the Xiaotan section, South China. Precambrian Research 225, 148-165.

Dumitrescu, M., Brassell, S.C., 2006. Compositional and isotopic characteristics of organic matter for the early Aptian Oceanic Anoxic Event at Shatsky Rise, ODP Leg 198. Palaeogeography, Palaeoclimatology, Palaeoecology 235, 168-191.

Farquhar, J., Bao, H., Thiemens, M., 2000. Atmospheric influence of Earth's earliest sulfur cycle. Science 289, 756-758.

Fennel, K., Follows, M., Falkowski, P.G., 2005. The co-evolution of the nitrogen, carbon and oxygen cycles in the Proterozoic ocean. American Journal of Science 305, 526-545. 
Fike, D.A., Grotzinger, J.P., Pratt, L.M., Summons, R.E., 2006. Oxidation of the Ediacaran Ocean. Nature 444, 744-747.

Fuchsman, C., Murray, J.W., Konovalov, S.K., 2008. Concentration and natural stable isotope profiles of nitrogen species in the Black Sea. Marine Chemistry 111, 88-103

Galbraith, E.D., Sigman, D., Pedersen, T., Robinson, R.S., 2008. Past changes in the marine nitrogen cycle, in: Capone, D., Bronk, D., Mulholland, M., Carpenter, E. (Eds) Nitrogen in the Marine Environment, $2^{\text {nd }}$ edition. Elsevier, pp 1497-1535.

Garvin, J., Buick, R., Anbar, A.D., Arnold, G.L., Kaufman, A.J., 2009. Isotopic Evidence for an Aerobic Nitrogen Cycle in the Latest Archean. Science 323, 1045-1048.

Godfrey, L.V., Falkowski, P.G., 2009. The cycling and redox state of nitrogen in the Archaean ocean. Nature Geosci 2, 725-729.

Godfrey, L.V., Poulton, S.W., Bebout, G.E., Fralick, P.W., 2013. Stability of the nitrogen cycle during development of sulfidic water in the redox-stratified late Paleoproterozoic Ocean. Geology 41, 655-658.

Granger, J., Sigman, D.M., Lehmann, M.F., Tortell, P.D., 2008. Nitrogen and oxygen isotope fractionation during dissimilatory nitrate reduction by denitrifying bacteria. Limnol. Oceanogr., $53,2533-2545$.

Halverson, G.P., 2011. Glacial sediments and associated strata of the Polarisbreen Group, northeastern Svalbard, in: Arnaud, E., Halverson, G.P., Shields-Zhou, G. (Eds.), The Geological Record of Neoproterozoic Glaciations. Geological Society Memoir 36, London, pp. 571-579.

Halverson, G.P. and Shields-Zhou, G., 2011. Chemostratigraphy and the Neoproterozoic glaciations. In: E. Arnaud, G.P. Halverson, and G. Shields-Zhou (Eds.) The Geological Record of Neoproterozoic Glaciations. Geological Society, London, Memoir 36, 51-66.

Higgins, M.B., Robinson, R.S., Carter, S.J., Pearson, A., 2010. Evidence from chlorin nitrogen isotopes for alternating nutrient regimes in the Eastern Mediterranean Sea. Earth and Planetary Science Letters 290, 102-107.

Higgins, M.B., Robinson, R.S., Husson, J.M., Carter, S.J., Pearson, A., 2012. Dominant eukaryotic export production during ocean anoxic events reflects the importance of recycled $\mathrm{NH}_{4}{ }^{+}$. PNAS 109, 2269-2274.

Hoffman, P.F., Schrag, D.P., 2002. The snowball Earth hypothesis: testing the limits of global change. Terra Nova 14, 129-155.

Jenkyns, H.C., Gröcke, D.R., Hesselbo, S.P., 2001. Nitrogen Isotope Evidence for Water Mass Denitrification during the Early Toarcian (Jurassic) Oceanic Anoxic Event. Paleoceanography $16,593-603$.

Jenkyns, H.C., Matthews, A., Tsikos, H., Erel, Y., 2007. Nitrate reduction, sulfate reduction, and sedimentary iron isotope evolution during the Cenomanian-Turonian oceanic anoxic event. Paleoceanography 22, PA3208. 
Jia, Y., 2006. Nitrogen isotope fractionations during progressive metamorphism: A case study from the Paleozoic Cooma metasedimentary complex, southeastern Australia. Geochimica et Cosmochimica Acta 70, 5201-5214.

Jia, Y., Kerrich, R., 2004. Nitrogen 15-enriched Precambrian kerogen and hydrothermal systems. Geochemistry, Geophysics, Geosystems 5, Q07005.

Johnston, D.T., Poulton, S.W., Goldberg, T., Sergeev, V.N., Podkovyrov, V., Vorob'eva, N.G., Bekker, A., Knoll, A.H., 2012. Late Ediacaran redox stability and metazoan evolution. Earth and Planetary Science Letters 335-336, 25-35.

Johnston, D.T., Poulton, S.W., Tosca, N.J., O'Brien, T., Halverson, G.P., Schrag, D.P., Macdonald, F.A., 2013. Searching for an oxygenation event in the fossiliferous Ediacaran of northwestern Canada. Chemical Geology. doi: 10.1016/j.chemgeo.2013.08.046.

Junium, C.K., Arthur, M.A., 2007. Nitrogen cycling during the Cretaceous, CenomanianTuronian Oceanic Anoxic Event II. Geochem. Geophys. Geosyst. 8, Q03002.

Kah, L.C., Bartley, J.K., 2011. Protracted oxygenation of the Proterozoic biosphere. International Geology Review 53, 1424-1442.

Kalvelage, T., Jensen, M.M., Contreras, S., Revsbech, N.P., Lam, P., Ganter, M., LaRoche, J., Lavik, G., Kuypers, M.M.M., 2011. Oxygen Sensitivity of Anammox and Coupled N-Cycle Processes in Oxygen Minimum Zones. PLoS ONE 6, e29299.

Kikumoto, R., Tahata, M., Nishizawa, M., Sawaki, Y., Maruyama, S., Shu, D., Han, J., Komiya, T., Takai, K., Ueno, Y., 2014. Nitrogen isotope chemostratigraphy of the Ediacaran and Early Cambrian platform sequence at Three Gorges, South China. Gondwana Research, 25, 10571069.

Kimura, H., Matsumoto, R., Kakuwa, Y., Hamdi, B., and Zibaseresht, H., 1997. The VendianCambrian $\delta^{13} \mathrm{C}$ record, North Iran: Evidence for overturning of the ocean before the Cambrian Explosion. Earth and Planetary Science Letters, 147, E1-E7.

Kump, L.R., Pavlov, A., and Arthur, M.A., 2005, Massive release of hydrogen sulfide to the surface ocean and atmosphere during intervals of oceanic anoxia: Geology, v. 33, p.397-400.

Kump, L., Junium, C., Arthur, M.A., Brasier, A., Fallick, A., Melezhik, V., Lepland, A., Crne, A.E., Luo, G., 2011. Isotopic Evidence for Massive Oxidation of Organic Matter Following the Great Oxidation Event. Science 334, 1694-1696.

Kuypers, M.M., van Breugel, Y., Schouten, S., Erba, E., Damsté, J.S.S., 2004. $\mathrm{N}_{2}$-fixing cyanobacteria supplied nutrient $\mathrm{N}$ for Cretaceous oceanic anoxic events. Geology 32, 853-856.

Kuypers, M.M., Blokker, P., Hopmans, E.C., Kinkel, H., Pancost, R.D., Schouten, S., Sinninghe Damsté, J.S., 2002. Archaeal remains dominate marine organic matter from the early Albian oceanic anoxic event 1b. Palaeogeography, Palaeoclimatology, Palaeoecology 185, 211-234. 
Lam P., Lavik, G., Jensen, M.M., van de Vossenberg J., Schmid, M., Woebken, D., Dimitri Gutiérrez D., Amann, R., Jetten, M.S.M., Kuypers, M.M.M., 2009. Revising the nitrogen cycle in the Peruvian oxygen minimum zone. PNAS 106, 4752-4757.

Lam, P., Kuypers, M.M.M., 2011. Microbial Nitrogen Cycling Processes in Oxygen Minimum Zones. Marine Science Annual Reviews 3, 317-345.

LaPorte, D.F., Holmden, C., Patterson, W.P., Loxton, J.D., Melchin, M.J., Mitchell, C.E., Finney, S.C., Sheets, H.D., 2009. Local and global perspectives on carbon and nitrogen cycling during the Hirnantian glaciation. Palaeogeography, Palaeoclimatology, Palaeoecology 276, 182195.

Lavik, G., Stuhrmann, T., Bruchert, V., Van der Plas, A., Mohrholz, V., Lam, P., Muszmann, M., Fuchs, B.M., Amann, R., Lass, U., Kuypers, M.M.M., 2009. Detoxification of sulphidic African shelf waters by blooming chemolithotrophs. Nature 457, 581-584.

Lehmann, M.F., Sigman, D.M., McCorkle, D.C., Granger, J., Hoffmann, S., Cane, G., Brunelle, B.G., 2007. The distribution of nitrate ${ }^{15} \mathrm{~N} /{ }^{14} \mathrm{~N}$ in marine sediments and the impact of benthic nitrogen loss on the isotopic composition of oceanic nitrate. Geochimica et Cosmochimica Acta 71, 5384-5404.

Levman, B.G., Bitter, P.H.v., 2002. The Frasnian-Famennian (mid-Late Devonian) boundary in the type section of the Long Rapids Formation, James Bay Lowlands, northern Ontario, Canada. Canadian Journal of Earth Sciences 39, 1795-1818.

Li, C., Evans, D.A.D., Halverson, G.P., 2013. Neoproterozoic glaciations in a revised global paleogeography from the breakup of Rodinia to the assembly of Gondwanaland. Sedimentary Geology 294, 219-232.

Li, C., Love, G.D., Lyons, T.W., Fike, D.A., Sessions, A.L., Chu, X., 2010. A Stratified Redox Model for the Ediacaran Ocean. Science 328, 80-83.

Li, C., Love, G.D., Lyons, T.W., Scott, C.T., Feng, L., Huang, J., Chang, H., Zhang, Q., Chu, X., 2012. Evidence for a redox stratified Cryogenian marine basin, Datangpo Formation, South China. Earth and Planetary Science Letters 331-332, 246-256.

Logan, G.A., Hayes, J.M., Hieshima, G.B., Summons, R.E., 1995. Terminal Proterozoic reorganization of biogeochemical cycles. Nature 376, 53-56.

Luo, G., Wang, Y., Algeo, T.J., Kump, L.R., Bai, X., Yang, H., Yao, L., Xie, S., 2011. Enhanced nitrogen fixation in the immediate aftermath of the latest Permian marine mass extinction. Geology 39, 647-650.

Lyons, T.W., Reinhard, C.T., Planavsky., N.J., 2014. The rise of oxygen in Earth's early ocean and atmosphere. Nature 506, 307-315.

Macdonald, F. A., Schmitz, M. D., Crowley, J. L., Roots, C. F., Jones, D. S., Maloof, A. C., Strauss, J. V., Cohen, P. A., Johnston, D. T., and Schrag, D. P., 2010. Calibrating the Cryogenian: Science 327, 1241-1243. 
Macouin, M., Besse, J., Ader, M., Gilder, S., Yang, Z., Sun, Z., Agrinier, P., 2004. Combined paleomagnetic and isotopic data from the Doushantuo carbonates, South China: implications for the "snowball Earth" hypothesis. Earth Planet. Sci. Lett. 224, 387-398.

Mandernack, K.W., Mills, C.T., Johnson, C.A., Rahn, T., Kinney, C., 2009. The $\delta^{15} \mathrm{~N}$ and $\delta^{18} \mathrm{O}$ values of $\mathrm{N}_{2} \mathrm{O}$ produced during the co-oxidation of ammonia by methanotrophic bacteria. Chemical Geology 267, 96-107.

Mariotti, A., Germon, J.C., Hubert, P., Kaiser, P., Letolle, R., Tardieux, A., Tardieux, P., 1981. Experimental determination of nitrogen kinetic isotope fractionation: Some principles; illustration for the denitrification and nitrification processes. Plant and Soil 62, 413-430.

McFadden, K.A., Huang, J., Chu, X., Jiang, G., Kaufman, A.J., Zhou, C., Yuan, X., Xiao, S., 2007. Pulsed oxidation and biological evolution in the Ediacaran Doushantuo Formation. PNAS 105, 3197-3202.

Meckler, A.N., Haug, G.H., Sigman, D.M., Plessen, B., Petersen, L.C., Thierstein, H.R., 2007. Detailed sedimentary $\mathrm{N}$ isotope records from Cariaco Basin for Terminations I and V: Local and global implications. Global Biogeochem. Cycles 21, GB4019.

Meyers, P.A., 2006. Paleoceanographic and paleoclimatic similarities between Mediterranean sapropels and Cretaceous black shales. Palaeogeography, Palaeoclimatology, Palaeoecology 235, 305-320.

Meyers, P.A., Bernasconi, S.M., 2005. Carbon and nitrogen isotope excursions in midPleistocene sapropels from the Tyrrhenian Basin: Evidence for climate-induced increases in microbial primary production. Marine Geology 220, 41-58.

Mingram, B., Brauer, K., 2001. Ammonium concentration and nitrogen isotope composition in metasedimentary rocks from different tectonometamorphic units of the European Variscan Belt. Geochimica et Cosmochimica Acta 65, 273-287.

Möbius, J., 2013. Isotope fractionation during nitrogen remineralization (ammonification): Implications for nitrogen isotope biogeochemistry. Geochimica et Cosmochimica Acta 105, 422432.

Narbonne, G.M., Gehling, J.G., 2003. Life after snowball: The oldest complex Ediacaran fossils. Geology 31, 27-30.

Och, L.M., Shields-Zhou, G.A., 2012. The Neoproterozoic oxygenation event: Environmental perturbations and biogeochemical cycling. Earth-Science Reviews 110, 26-57.

Olcott, A.N., Sessions, A.L., Corsetti, F.A., Kaufman, A.J., de Oliviera, T.F., 2005. Biomarker Evidence for Photosynthesis During Neoproterozoic Glaciation. Science 310, 471-474.

Pantke, C., Obst, M., Benzerara, K., Morin, G., Ona-Nguema, G., Dippo, U., Kappler, A., 2012. Green Rust during Fe(II) Oxidation by Nitrate-ReducingAcidovoraxsp. Strain BoFeN1. Environmental Science and Technology 46, 1439-1446. 
Papineau, D., Purohit, R., Goldberg, T., Pi, D., Shields, G.A., Bhu, H., Steele, A., Fogel, M.L., 2009. High primary productivity and nitrogen cycling after the Paleoproterozoic phosphogenic event in the Aravalli Supergroup, India. Precambrian Research 171, 37-56.

Papineau, D., Purohit, R., Fogel, M.L., Shields-Zhou, G.A., 2013. High phosphate availability as a possible cause for massive cyanobacterial production of oxygen in the Paleoproterozoic atmosphere. Earth and Planetary Science Letters 362, 225-236.

Partin, C.A., Bekker, A., Planavsky, N.J., Scott, C.T., Gill, B.C., Li, C., Podkovyrov, V., Maslov, A., Konhauser, K.O., Lalonde, S.V., Love, G.D., Poulton, S.W., Lyons, T.W., 2013. Large-scale fluctuations in Precambrian atmospheric and oceanic oxygen levels from the record of $U$ in shales. Earth and Planetary Science Letters 369-370, 284-293.

Pawlowska, M.M., Butterfield, N.J., Brocks, J.J., 2013. Lipid taphonomy in the Proterozoic and the effect of microbial mats on biomarker preservation. Geology 41, 103-106.

Pennock, J.R., Velinsky, D.J., Ludlam, J.M., Sharp, J.H., Fogel, M.L., 1996. Isotopic fractionation of ammonium and nitrate during uptake by Skeletonema costatum: Implications for $\delta^{15} \mathrm{~N}$ dynamics under bloom conditions. Limnology and Oceanography 41, 451-459.

Pinti, D.L., Hashizume, K. Sugihara, A., Massault, M., Philippot, P., 2009. Isotopic fractionation of nitrogen and carbon in Paleoarchean cherts from Pilbara craton, Western Australia: Origin of ${ }^{15} \mathrm{~N}$-depleted nitrogen. Geochimica et Cosmochimica Acta 73, 3819-3848.

Planavsky, N.J., McGoldrick, P., Scott, C.T., Li, C., T. Reinhard, C.T., Kelly, A.E., Chu, X., Bekker, A., Love, G.D., W. Lyons, T.W., 2011. Widespread iron-rich conditions in the midProterozoic ocean. Nature 477, 448-451.

Poulton, S.W., Canfield, D.E., 2011. Ferruginous conditions: a dominant feature of the Ocean through Earth's history. Elements 7, 107-112.

Quan, T.M., Falkowski, P.G., 2009. Redox control of N:P ratios in aquatic ecosystems. Geobiology 7, 124-139.

Quan, T.M., van de Schootbrugge, B., Field, M.P., Rosenthal, Y., Falkowski, P.G., 2008. Nitrogen isotope and trace metal analyses from the Mingolsheim core (Germany): Evidence for redox variations across the Triassic-Jurassic boundary. Global Biogeochem. Cycles 22, GB2014.

Reinhard, C.T., Planavsky, N.J., Robbins, L.J., Partin, C.A., Gill, B.C., Lalonde, S.V., Bekker, A., Konhauser, K.O., Lyons, T.W., 2013. Proterozoic ocean redox and biogeochemical stasis. Proceedings of the National Academy of Sciences 110, 5357-5362.

Robinson, R.S., Kienast, M., Luiza Albuquerque, A., Altabet, M., Contreras, S., De Pol Holz, R., Dubois, N., Francois, R., Galbraith, E., Hsu, T.-C., Ivanochko, T., Jaccard, S., Kao, S.-J., Kiefer, T., Kienast, S., Lehmann, M., Martinez, P., McCarthy, M., Möbius, J., Pedersen, T., Quan, T.M., Ryabenko, E., Schmittner, A., Schneider, R., Schneider-Mor, A., Shigemitsu, M., Sinclair, D., Somes, C., Studer, A., Thunell, R., Yang, J.-Y., 2012. A review of nitrogen isotopic alteration in marine sediments. Paleoceanography 27, PA4203. 
Sachs, J.P., Repeta, D.J., Goericke, R., 1999. Nitrogen and carbon isotopic ratios of chlorophyll from marine phytoplankton. Geochimica et Cosmochimica Acta 63, 1431-1441.

Sahoo, S.K., Planavsky, N.J., Kendall, B., Wang, X., Shi, X., Scott, C., Anbar, A.D., Lyons, T.W., Jiang, G., 2012. Ocean oxygenation in the wake of the Marinoan glaciation. Nature 489, 546-549.

Sansofre, P., 2011. L'environnement post-marinoen (ca. $635 \mathrm{ma}$ ) : une étude multi-proxy de la plateforme carbonatée du Groupe d'Araras (Mato Grosso, Brésil). PhD thesis, Université ParisDiderot, pp 287.

Sansjofre, P., Ader, M., Trindade, R.I.F., Elie, M., Lyons, J., Cartigny, P., Nogueira, A.C.R., 2011. A carbon isotope challenge to the snowball Earth. Nature 478, 93-96.

Sansjofre, P., Trindade, R.I.F., Ader, M., Soares, J.L., Nogueira, A.C.R., Tribovillard, N., 2014. Paleoenvironmental reconstruction of the Ediacaran Araras platform (Western Brazil) from the sedimentary and trace metals record. Precambrian Research, 241, 185-202.

Santoro, A.E., Casciotti, K.L., 2011. Enrichment and characterization of ammonia-oxidizing archaea from the open ocean: phylogeny, physiology and stable isotope fractionation. ISME J 5, 1796-1808.

Scholz, F., Severmann, S., McManus, J., Hensen, C., 2014. Beyond the Black Sea paradigm: The sedimentary fingerprint of an open-marine iron shuttle. Geochimica et Cosmochimica Acta 127, 368-380.

Schroder, S., Grotzinger, J.P., 2007. Evidence for anoxia at the Ediacaran-Cambrian boundary: the record of redox-sensitive trace elements and rare earth elements in Oman. Journal of Geological Society of London 164, 175-187.

Scott, C., Lyons, T.W., Bekker, A., Shen, Y., Poulton, S.W., Chu, X., Anbar, A.D., 2008. Tracing the stepwise oxygenation of the proterozoic ocean. Nature 452, 456-459.

Shen, B., Xiao, S., Bao, H., Kaufman, A.J., Zhou, C., Yuan, X., 2011. Carbon, sulfur, and oxygen isotope evidence for a strong depth gradient and oceanic oxidation after the Ediacaran Hankalchough glaciation? Geochimica et Cosmochimica Acta 75, 1357-1373.

Sigman, D.M., DiFiore, P.J., Hain, M.P., Deutsch, C., Wang, Y., Karl, D.M., Knapp, A.N., Lehmann, M.F., Pantoja, S., 2009a. The dual isotopes of deep nitrate as a constraint on the cycle and budget of oceanic fixed nitrogen. Deep Sea Research Part I: Oceanographic Research Papers $56,1419-1439$.

Sigman, D.M., Karsh, K.L., Casciotti, K.L., 2009b. Nitrogen isotopes in the ocean, in: Steele, J.H., Thorpe, S.A., Turekian, K.K. (Eds) Encyclopedia of Ocean Sciences. Academic Press, Oxford, pp. 40-54.

Sliwinski, M.G., Whalen, M.T., Newberry, R.J., Payne, J.H., Day, J.E., 2011. Stable isotope $\left(\delta^{13} \mathrm{Ccarb}\right.$ and org, $\left.\delta^{15} \mathrm{Norg}\right)$ and trace element anomalies during the Late Devonian 'punctata Event' in the Western Canada Sedimentary Basin. Palaeogeography, Palaeoclimatology, Palaeoecology 307, 245-271. 
Somes, C.J., Schmittner, A., Galbraith, E.D., Lehmann, M.F., Altabet, M.A., Montoya, J.P., Letelier, R.M., Mix, A.C., Bourbonnais, A., Eby, M., 2010. Simulating the global distribution of nitrogen isotopes in the ocean. Global Biogeochem. Cycles 24, GB4019.

Spangenberg, J.E., Bagnoud-VelÃ $j$ squez, M., Boggiani, P.C., Gaucher, C., 2014. Redox variations and bioproductivity in the Ediacaran: Evidence from inorganic and organic geochemistry of the Corumbá Group, Brazil. Gondwana Research. doi 10.1016/j.gr.2013.08.014.

Sperling, E.A., Halverson, G.P., Knoll, A.H., Macdonald, F.A., Johnston, D.T., 2013. A basin redox transect at the dawn of animal life. Earth and Planetary Science Letters 371-372, 143-155.

Stüeken, E.E., 2013. A test of the nitrogen-limitation hypothesis for retarded eukaryote radiation: Nitrogen isotopes across a Mesoproterozoic basinal profile. Geochimica et Cosmochimica Acta 120, 121-139.

Tesdal, J.E., Galbraith, E.D., Kienast, M., 2013. Nitrogen isotopes in bulk marine sediment: linking seafloor observations with subseafloor records. Biogeosciences 10, 101-118.

Thamdrup, B., Dalsgaard, T., Revsbech, N.P., 2012. Widespread functional anoxia in the oxygen minimum zone of the Eastern South Pacific. Deep Sea Research Part I: Oceanographic Research Papers 65, 36-45.

Thomazo, C., Ader, M., Philippot, P., 2011. Extreme ${ }^{15} \mathrm{~N}$-enrichments in 2.72-Gyr-old sediments: evidence for a turning point in the nitrogen cycle. Geobiology 9, 107-120.

Thomazo, C., Pinti, D.L., Busigny, V., Ader, M., Hashizume, K., Philippot, P., 2009. Biological activity and the Earth's surface evolution: Insights from carbon, sulfur, nitrogen and iron stable isotopes in the rock record. Comptes Rendus Palevol 8, 665-678.

Thunell, R.C., Sigman, D.M., Muller-Karger, F., Astor, Y., Varela, R., 2004. Nitrogen isotope dynamics of the Cariaco Basin, Venezuela. Global Biogeochem. Cycles 18, GB3001.

Voss, M., Dippner, J.W., Montoya, J.P., 2001. Nitrogen isotope patterns in the oxygen-deficient waters of the Eastern Tropical North Pacific Ocean. Deep Sea Research Part I: Oceanographic Research Papers 48, 1905-1921.

Wang, L., Shi, X., Jiang, G., 2012. Pyrite morphology and redox fluctuations recorded in the Ediacaran Doushantuo Formation. Palaeogeography, Palaeoclimatology, Palaeoecology 333, 218-227.

Weber, K.A., Achenbach, L.A., Coates, J.D., 2006. Microorganisms pumping iron: anaerobic microbial iron oxidation and reduction. Nat Rev Micro 4, 752-764.

Wenk, C.B., Blees, J., Zopfi, J., Veronesi, M.L., Bourbonnais, A., Schubert, C.J., Niemann, H., Lehmann, M.F., 2013. Anaerobic ammonium oxidation (anammox) bacteria and sulfidedependent denitrifiers coexist in the water column of a meromictic south-alpine lake. Limnology and Oceanography, 58, 1-12. 
870 Wenk, C.B., Zopfi, J., Blees, J., Veronesi, M., Niemann, H., Lehmann, M.F., 2014. Community

$871 \mathrm{~N}$ and $\mathrm{O}$ isotope fractionation by sulfide-dependent denitrification and anammox in a stratified

872 lacustrine water column. Geochimica et Cosmochimica Acta, 125, 551-563

873 Yui, T.-F., Kao, S.-J., Wu, T.-W., 2009. Nitrogen and $\mathrm{N}$-isotope variation during low-grade 874 metamorphism of the Taiwan mountain belt. Geochemical Journal 43, 15-27.

875 Zerkle, A.L., Junium, C.K., Canfield, D.E., House, C.H., 2008. Production of ${ }^{15}$ N-depleted 876 biomass during cyanobacterial $\mathrm{N}_{2}$-fixation at high Fe concentrations. J. Geophys. Res. 113, 877 G03014.

878

879

Figure legends

880

Figure 1: Schematic representation of the nitrogen cycle and resulting nitrogen-isotopic imprint

881 on marine sediments (a) in a modern-like oxic ocean in which oxygen penetrates into the

882

883

884

885

886

887

888

889

890

891 892 fractionation $\left(\varepsilon_{\mathrm{ap}}\right)$ is close to nil. sediment except in OMZs where denitrification does not reach completion, (b) in a redoxstratified ocean with a relatively deep redox transition zone, where nitrate and ammonium are quantitatively converted to $\mathrm{N}_{2} / \mathrm{N}_{2} \mathrm{O}$ at the redox transition zone, except at vigorous upwelling locations where ammonium is nitrified concurrently with conversion to gaseous species, (c) in a redox stratified ocean with a shallow redox transition zone stabilizing below the surface mixed layer, except in upwelling zones where anoxic waters may reach the surface, allowing ammonium to be assimilated at the same time as being converted to $\mathrm{N}_{2}$ and $\mathrm{N}_{2} \mathrm{O}$, c) in our model for the 750 to $580 \mathrm{Ma}$ ocean with extended and severely OMZz and limited oxygen penetration in surface sediments. The red color indicates anoxic waters and the blue color oxygenated waters. $\varepsilon_{\mathrm{ap}} \approx 0$ indicates cases where the reaction is complete so that the apparent isotope 
894 Figure 2: Comparison of $\delta^{15} \mathrm{~N}_{\text {sed }}$ distribution in modern oceanic sediments, in Phanerozoic 895 anoxic events and in Neoproterozoic sediments. (a) Modern sediment $\delta^{15} \mathrm{~N}_{\text {sed, }}$ modified after 896 Tesdal et al. (2013). (b) $\delta^{15} \mathrm{~N}_{\text {sed }}$ from anoxic events in the Phanerozoic: (i) in black, the 897 Cretaceous ocean anoxic events OAEs 1a, 1b, 1d and 2 (Arnaboldi and Meyers, 2006; 898 Dumitrescu and Brassel, 2006; Jenkyns et al., 2007; Junium and Arthur, 2007; Kuypers et al., 899 2002, 2004; Meyers 2006); (ii) in dark grey, early Toarcian OAE (T-OAE) (Jenkyns et al., 900 2001); (iii) in light grey, the Quaternary and Cenozoic Mediterranean sapropels (Higgins et al., 901 2010; Meyers and Bernasconi, 2005; Sachs et al., 1999); (iv) in white, other Phanerozoic anoxic 902 events, of unknown spatial extent, which correspond to the Triassic-Jurassic transition (Quan et 903 al., 2008), the Permian-Triassic transition (Cao et al., 2009; Luo et al., 2011), the late Devonian 904 (Calvert et al., 1996; Levman and Bitter, 2002; Sliwinski et al., 2011), the late Ordovician 905 (LaPorte et al., 2009) and the early Cambrian (Cremonese et al., 2013). (c) Histogram of the $906 \delta^{15} \mathrm{~N}_{\text {sed }}$ data for the Yangtze platform (South China craton): in grey, data from the Yangjiaping 907 section representative of the shelf margin (this study), in white, previously published data from 908 the top of the Dengying Formation in the Xiaotan section (Cremonese et al., 2013) and the 909 Doushantuo and Dengying formations in the Wuhe section, representative of the inner shelf 910 basin (Kikumoto et al., 2014). (d) $\delta^{15} \mathrm{~N}_{\text {sed }}$ distributions for Brazil: in black, data from the Amazon

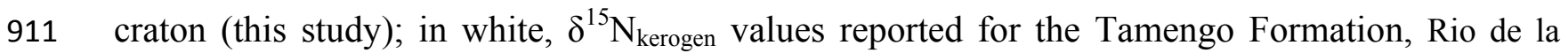
912 Plata craton (Spangenberg et al., 2014). (e) $\delta^{15} \mathrm{~N}_{\text {sed }}$ values for northwestern Canada (white) and 913 Svalbard (grey). (f) Histogram of all the $\delta^{15} \mathrm{~N}_{\text {sed }}$ (and $\delta^{15} \mathrm{~N}_{\text {kerogen}}$ ) data obtained in this study 914 compiled with the previous late Neoproterozoic data (Cremonese et al., 2013; Kikumoto et al., 915 2014; Spangenberg et al., 2014). (g) Histogram of published $\delta^{15} \mathrm{~N}_{\text {sed }}$ and $\delta^{15} \mathrm{~N}_{\text {kerogen }}$ data for 916 Paleoproterozoic and Mesoproterozoic successions: 1.4-1.5 Ga Belt Basin, Montana $\left(\delta^{15} \mathrm{~N}_{\text {sed }}\right.$ 
917 from Stüeken et al., 2013); 1.8-1.9 Ga Animikie Basin, North America $\left(\delta^{15} \mathrm{~N}_{\text {sed }}\right.$ from Godfrey et 918 al., 2013); 2.0-2.1 Ga Onega Basin, NW Russia ( $\delta^{15} \mathrm{~N}_{\text {kerogen }}$ from Kump et al., 2011) and 1.9-2.1

919 Ga Aravilli group, India ( $\delta^{15} \mathrm{~N}_{\text {sed }}$ from Papineau et al., 2009, 2013).

Figure 3: Paleogeographic reconstruction for $630 \mathrm{Ma}$ (Modified from Li et al., 2013). Red

922 empty stars indicate the locations of the four sample sets (South China, Amazon, NW Canada and NE Svalbard).

Figure 4: Chemostratigraphic representation of the present study $\delta^{15} \mathrm{~N}_{\text {sed }}$ results together with 926 available $\delta^{13} \mathrm{C}_{\text {carb }}$ and $\delta^{13} \mathrm{C}_{\text {org }}$ data. (a-c) Sections spanning the Araras platform on the 927 southeastern margin of the Amazonian craton (Fig. S1): (a) Composite Terconi-Camil section; 928 (b) Carmelo section; (c) Copacel section. For Camil, Carmelo and Copacel sections, $\delta^{13} \mathrm{C}_{\text {carb }}$ and $929 \delta^{13} \mathrm{C}_{\mathrm{org}}$ are from Sansjofre (2011) and for Terconi section from Sansjofre et al. (2011). (d) 930 Yangjiaping section, Shelf margin of the Yangtze platform, South China craton. $\delta^{13} \mathrm{C}_{\text {carb }}$ and $931 \delta^{13} \mathrm{C}_{\text {org }}$ are from Macouin et al. (2004) and Ader et al. (2009). (e) Composite northeast Svalbard 932 section. Previously published $\delta^{13} \mathrm{C}_{\text {carb }}$ and $\delta^{13} \mathrm{C}_{\text {org }}$ are from Halverson (2011). (f) Composite 933 northwest Canada section. $\delta^{13} \mathrm{C}_{\text {carb }}$ are from Hoffman and Schrag (2002).

935 Figure 5: $\mathrm{N}$ and $\delta^{15} \mathrm{~N}_{\text {sed }}$ data analyses. (a) Cross-plots of $\delta^{15} \mathrm{~N}_{\text {sed }}$ values with the nitrogen content 936 in ppm in the decarbonated residue $\left(\mathrm{N}_{\text {decarb }} \mathrm{ppm}\right)$. (b) Cross-plots of $\delta^{15} \mathrm{~N}_{\text {sed }}$ values with C/N. (c) 937 Cross-plots of $\mathrm{N}_{\text {decarb }}$ ppm with $\mathrm{TOC}_{\text {decarb }}$ ppm in log scales showing a broad correlation passing 
938 through the origin, as expected in the case of an organic origin for the sedimentary nitrogen. (d)

939 Cross-plots of $\delta^{15} \mathrm{~N}_{\text {sed }}$ values with $\delta^{13} \mathrm{C}_{\text {org }}$ showing no correlation.

940

941 Figure 6: Summary figure showing the major features of biospheric and paleoenvironmental

942 evolution from the early Neoproterozoic to the early Cambrian. Ranges of eukaryotes

943 summarized from Macdonald et al. (2010). Composite carbonate $\delta^{13} \mathrm{C}$ profile modified from

944 Halverson and Shields-Zhou (2011). Mo concentrations in euxinic black shales from Sahoo et al.

945 (2012). Nitrogen isotope data from this contribution, Cremonese et al. (2013), Kikumoto et al.

946 (2014), and Spangenberg et al. (2014). 


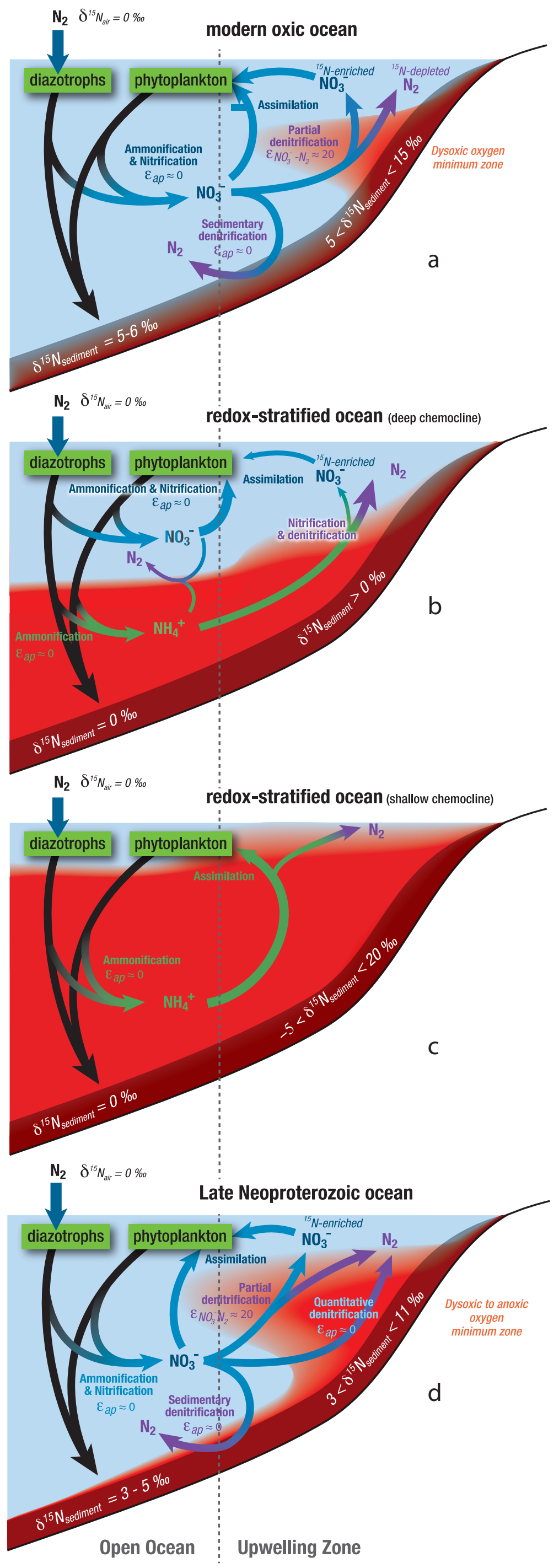




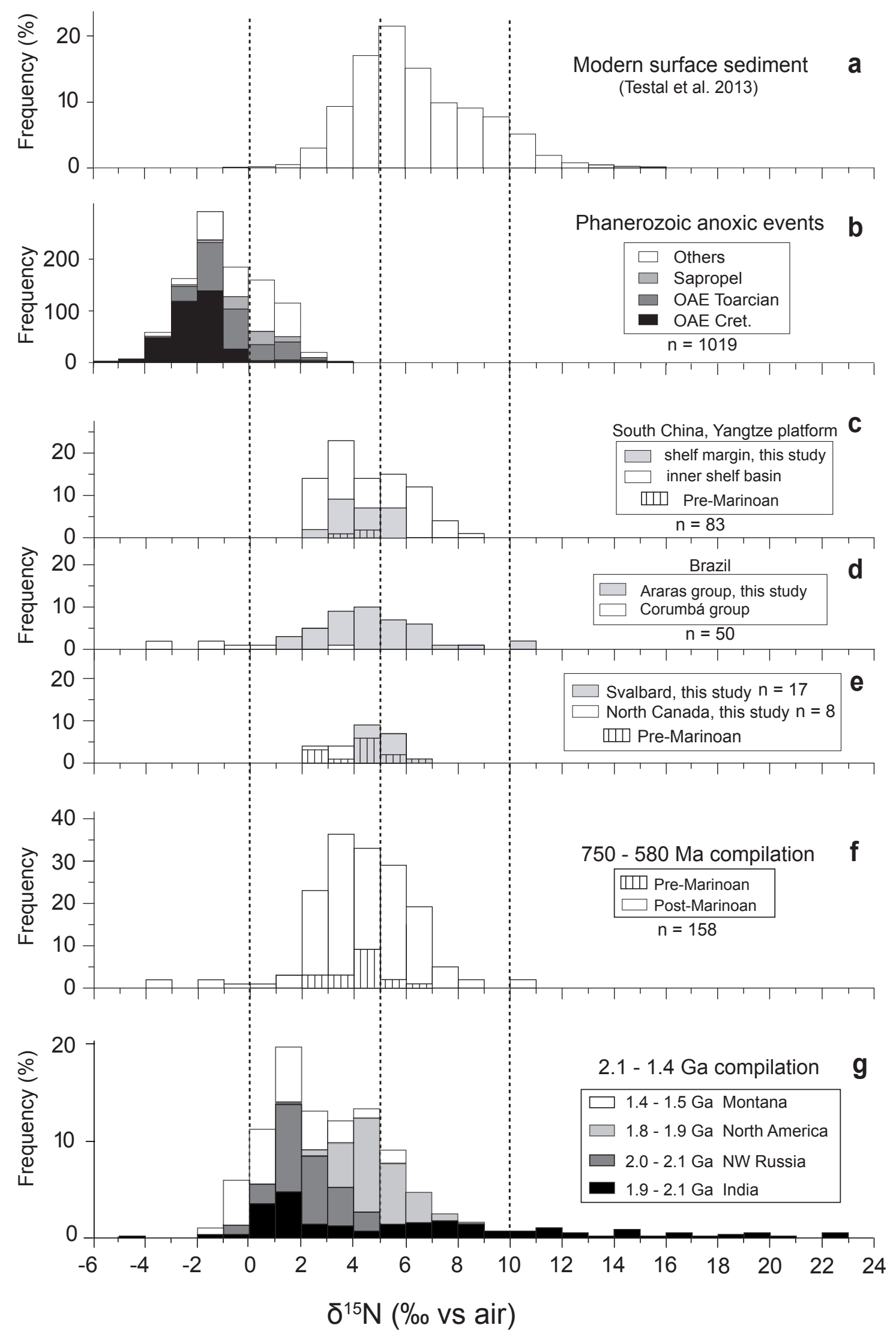




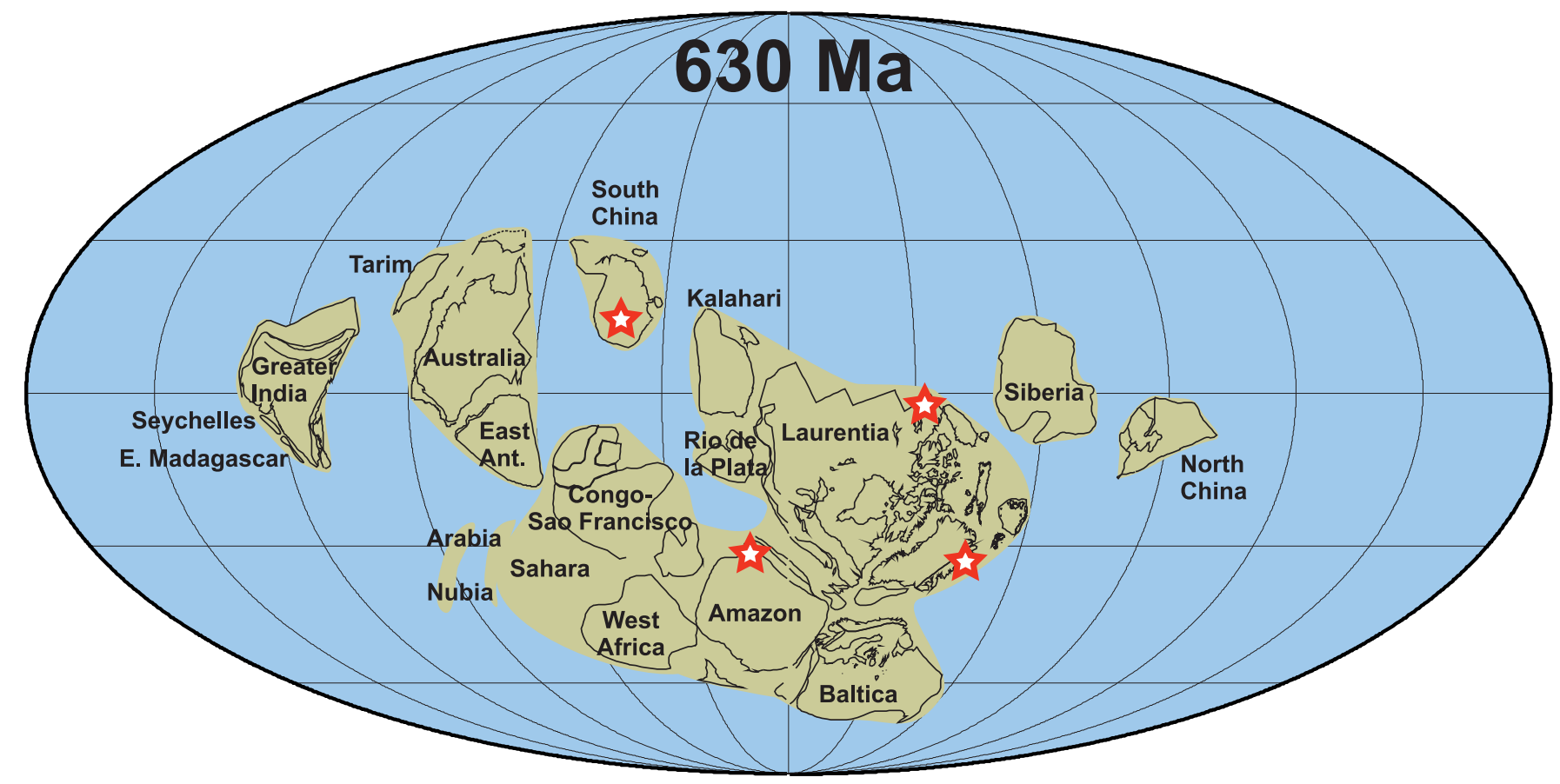


Araras platform, Amazon craton, Brazil
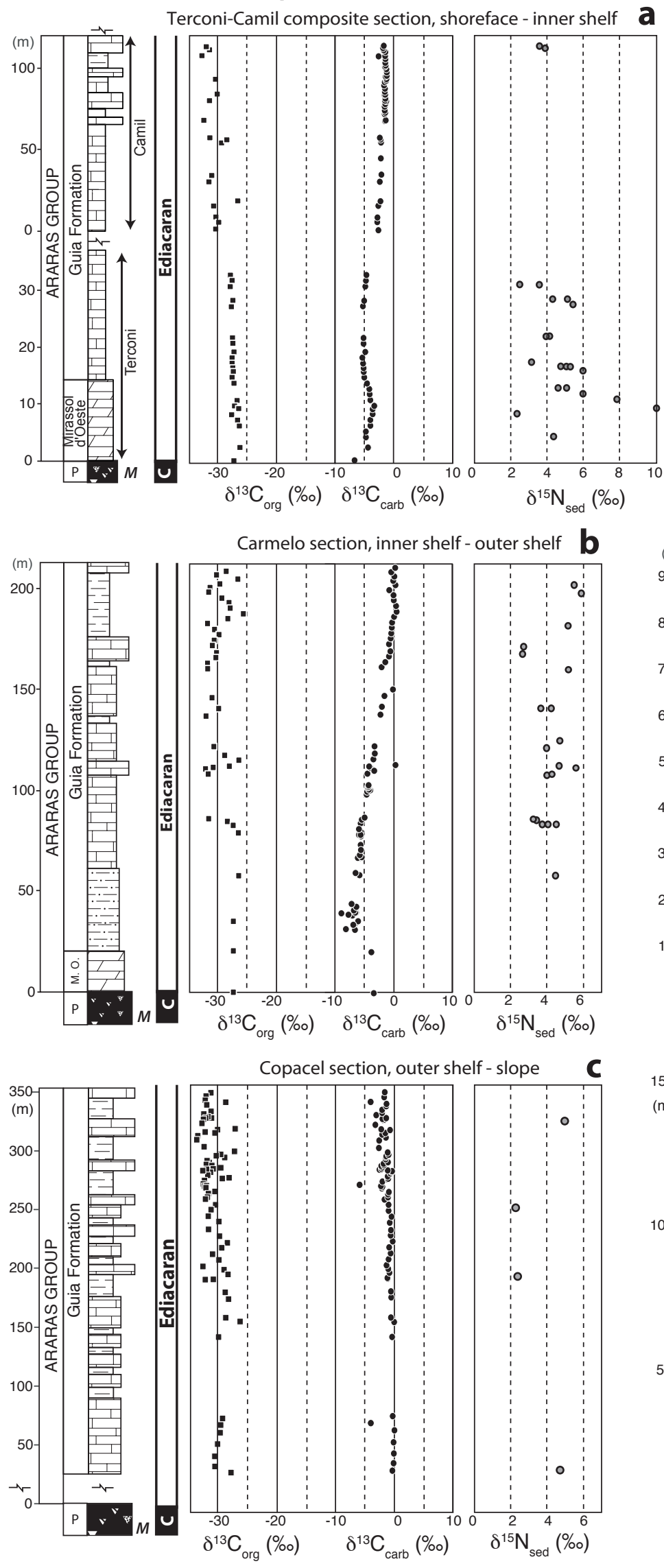
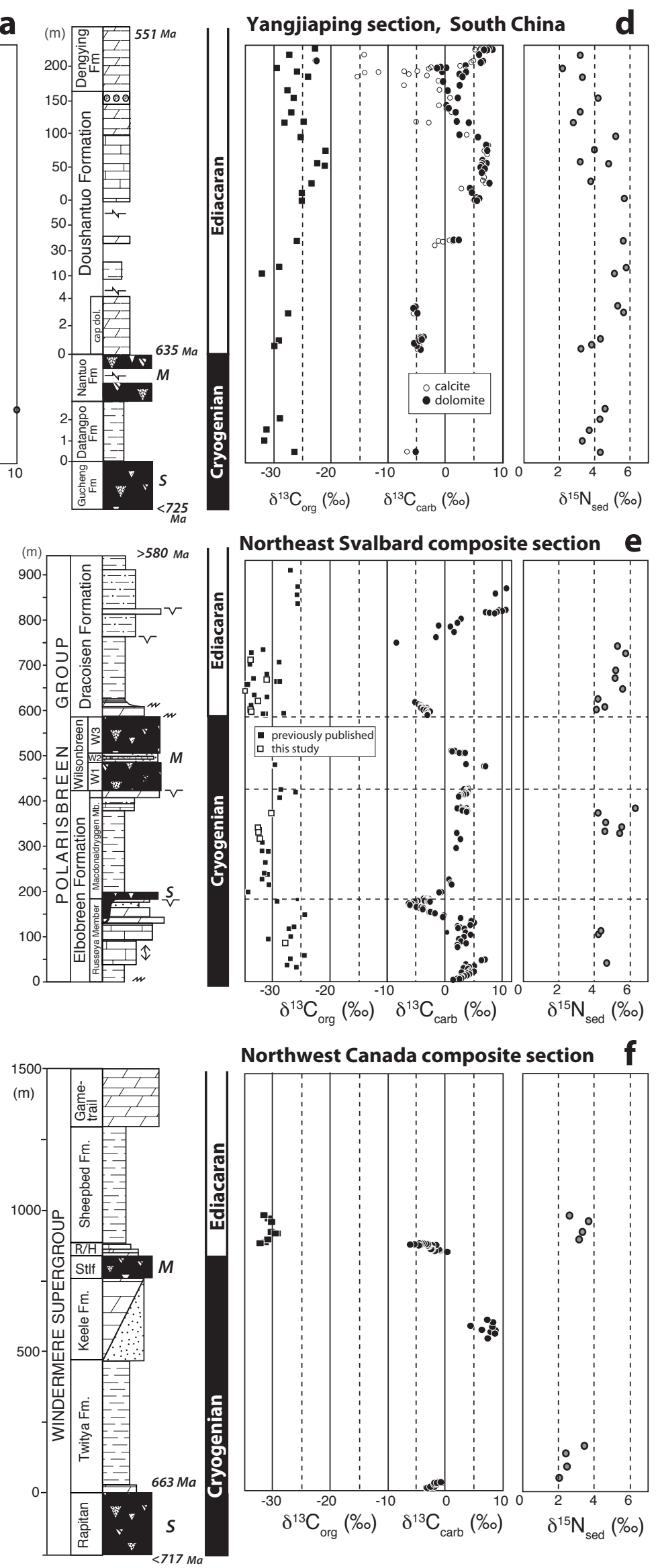

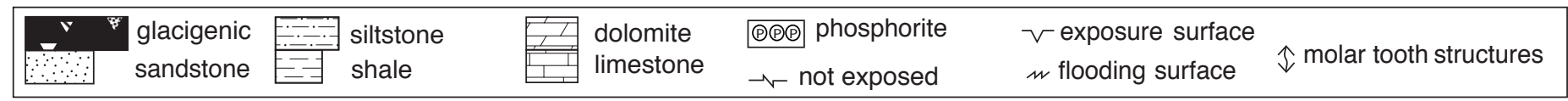



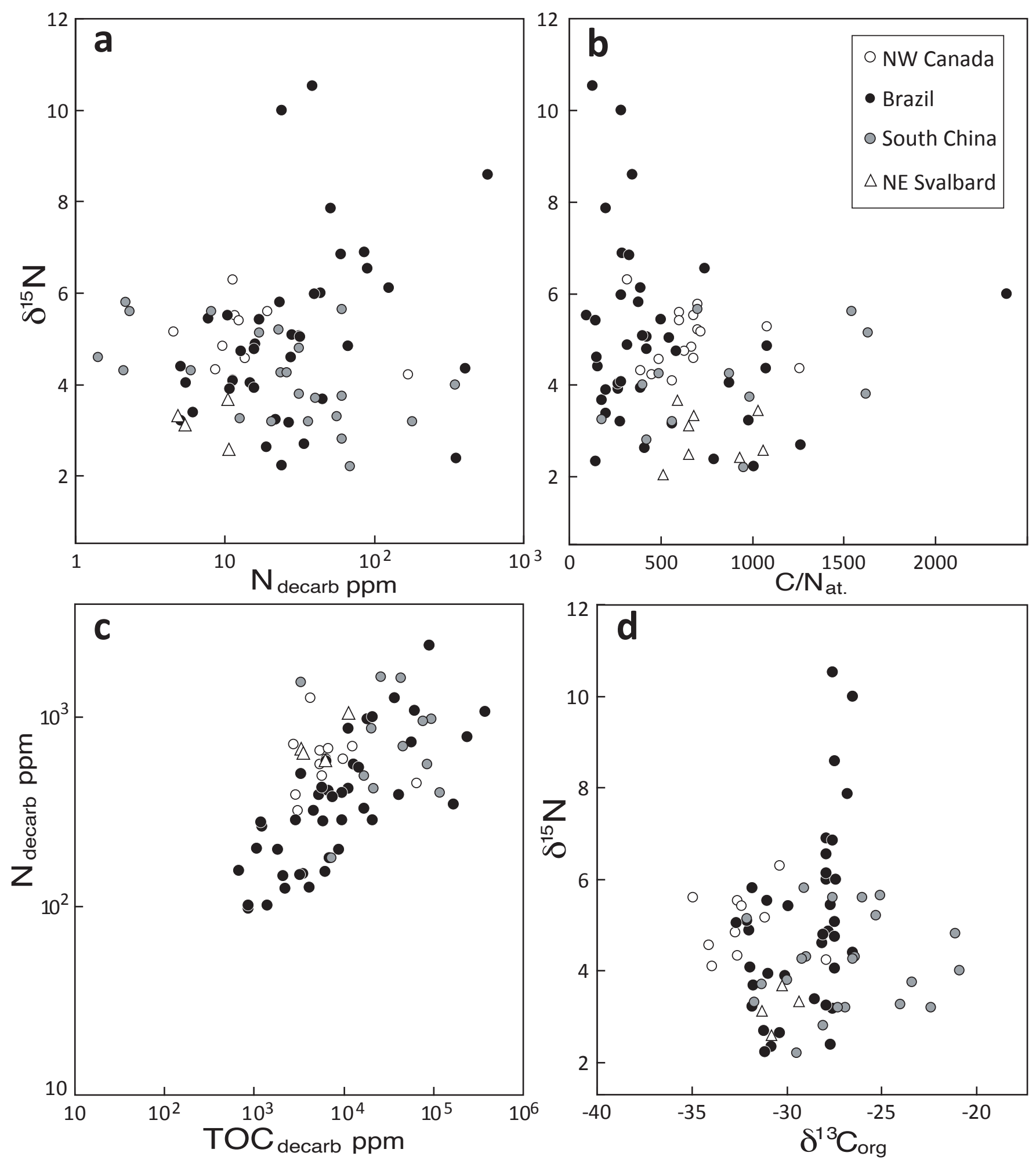


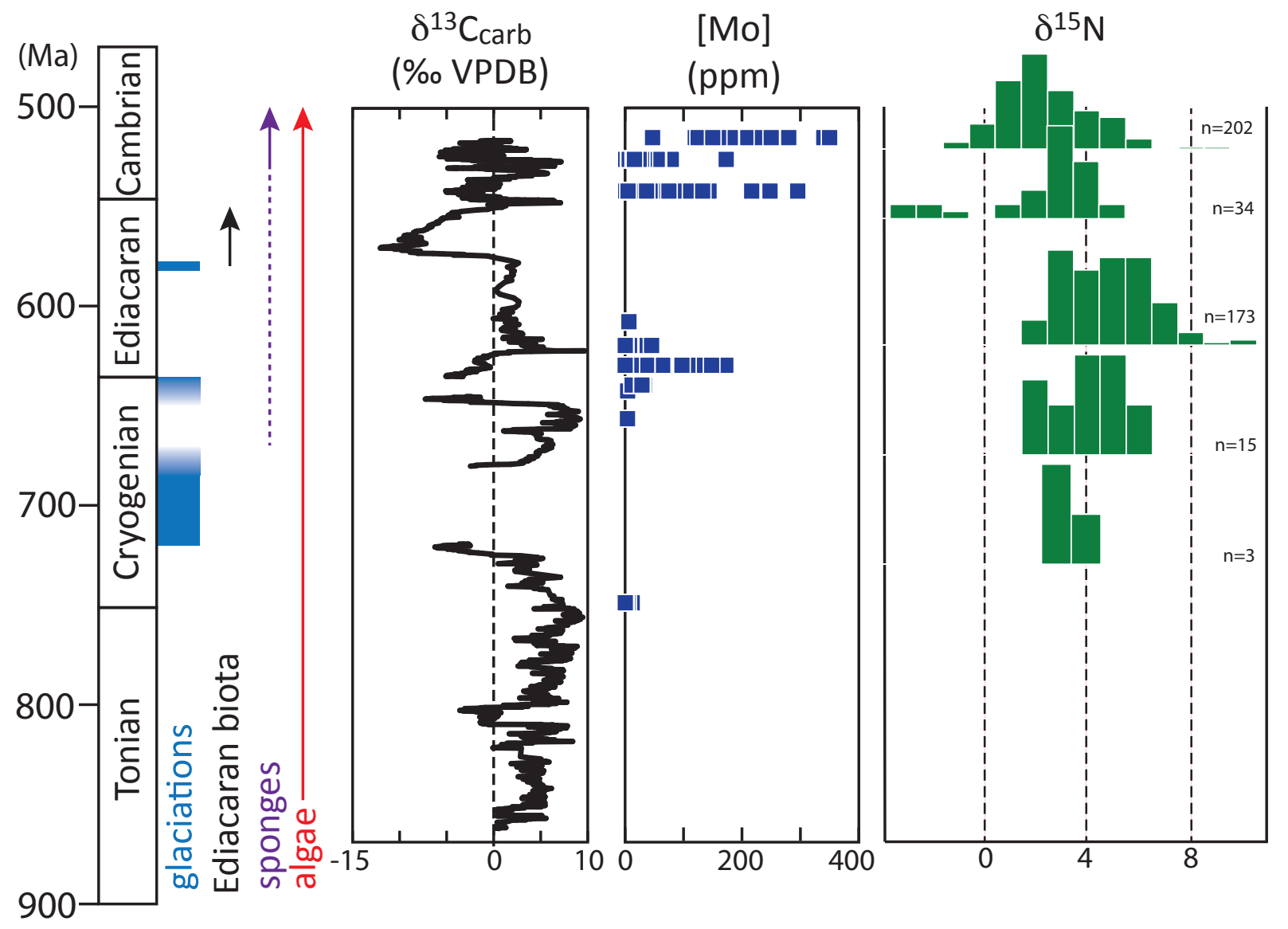


Table S1: FeT/Al ratios for Svalbard shales from the three units samples for nitrogen isotope analyses.

\begin{tabular}{|c|c|c|}
\hline Sample & Stratigraphic unit & $\mathrm{FeT} / \mathrm{A}$ \\
\hline G436.138 & lower Dracoisen Fm & 0.37 \\
\hline G436.120 & lower Dracoisen Fm & 0.51 \\
\hline G436.105 & lower Dracoisen Fm & 0.71 \\
\hline G436.101.5 & lower Dracoisen Fm & 0.42 \\
\hline G436.95.5 & lower Dracoisen Fm & 0.45 \\
\hline G436.88 & lower Dracoisen Fm & 0.42 \\
\hline G436.64 & lower Dracoisen Fm & 0.44 \\
\hline G436.42 & lower Dracoisen Fm & 0.40 \\
\hline G436.10.5 & lower Dracoisen Fm & 0.49 \\
\hline G435.79.5 & MacDonaldryggen Mbr & 0.61 \\
\hline G435.76 & MacDonaldryggen Mbr & 0.62 \\
\hline G435.66 & MacDonaldryggen Mbr & 0.57 \\
\hline G435.56 & MacDonaldryggen Mbr & 0.58 \\
\hline G435.45 & MacDonaldryggen Mbr & 0.55 \\
\hline G435.35 & MacDonaldryggen Mbr & 0.48 \\
\hline G435.25 & MacDonaldryggen Mbr & 0.43 \\
\hline G435.18 & MacDonaldryggen Mbr & 0.32 \\
\hline G521.46 & lower Russøya Mbr & 0.37 \\
\hline G521.44.4 & lower Russøya Mbr & 0.55 \\
\hline G521.40.5 & lower Russøya Mbr & 0.97 \\
\hline G521.36 & lower Russøya Mbr & 0.59 \\
\hline G521.33 & lower Russøya Mbr & 1.16 \\
\hline G521.30 & lower Russøya Mbr & 0.27 \\
\hline G521.26.4 & lower Russøya Mbr & 0.84 \\
\hline G521.23.4 & lower Russøya Mbr & 0.66 \\
\hline G521.19.6 & lower Russøya Mbr & 0.45 \\
\hline G521.18.9 & lower Russøya Mbr & 0.19 \\
\hline G521.13.2 & lower Russøya Mbr & 0.22 \\
\hline G521.6.2 & lower Russøya Mbr & 0.24 \\
\hline G521.3.7 & lower Russøya Mbr & 0.34 \\
\hline \multicolumn{3}{|c|}{ Detrital baseline } \\
\hline G526f & Wilsonbreen Fm & 0.55 \\
\hline G526j & Wilsonbreen Fm & 0.61 \\
\hline
\end{tabular}


Table S2: Comparison of nitrogen content and $\delta^{15} \mathrm{~N}$ results obtained for bulk and decarbonated samples, measured by either static or by conventional isotope ratio mass spectrometry.

\begin{tabular}{|c|c|c|c|c|c|c|c|c|c|c|}
\hline \multirow{4}{*}{$\begin{array}{c}\text { Samples } \\
\text { name }\end{array}$} & \multirow{4}{*}{$\begin{array}{c}\text { decarb }^{\mathrm{a}} \\
\text { wt } \%\end{array}$} & \multicolumn{4}{|c|}{ Bulk samples } & \multicolumn{4}{|c|}{ Decarbonated samples } & \multirow{4}{*}{$\begin{array}{c}\text { Average } \\
\delta^{\mathbf{1 5}} \mathbf{N} \%\end{array}$} \\
\hline & & \multicolumn{2}{|c|}{ Static } & \multicolumn{2}{|c|}{ Conventional } & \multicolumn{2}{|c|}{ Static } & \multicolumn{2}{|c|}{ Conventional } & \\
\hline & & $\mathrm{N}_{\text {bulk }}$ & $\delta^{15} \mathbf{N}$ & $\mathrm{N}_{\text {bulk }}$ & $\delta^{15} \mathbf{N}$ & $\mathrm{N}_{\text {bulk }}$ & $\delta^{15} \mathbf{N}$ & $\mathrm{N}_{\text {bulk }}$ & $\delta^{15} \mathbf{N}$ & \\
\hline & & $\mathrm{ppm}$ & $\pm 0.3 \%$ & $\mathrm{ppm}$ & $\pm 0.15 \%$ & ppm & $\pm 0.3 \%$ & ppm & $\pm 0.15 \%$ & \\
\hline TeS 46 & 93 & 60 & 3.6 & & & 63 & 2.5 & 71 & 3.6 & $3.2 \pm 0.63$ \\
\hline TeS 30 & 80 & 97 & 5.3 & & & 81 & 5.1 & 81 & 4.8 & $5.1 \pm 0.25$ \\
\hline CRS 16 & 60 & & & & & 301 & 5.1 & 300 & 4.6 & $4.8 \pm 0.30$ \\
\hline$\delta \mathrm{XM} 01$ & 10 & 770 & 4.1 & & & & & 530 & 3.3 & $3.7 \pm 0.55$ \\
\hline XM0107 & 11 & 945 & 4.2 & 970 & 4.7 & & & 980 & 4.0 & $4.3 \pm 0.35$ \\
\hline do1008 & 93 & 70 & 4.4 & & & 61 & 4.1 & & & $4.3 \pm 0.21$ \\
\hline do1013 & 59 & 685 & 5.4 & & & & & 630 & 5.8 & $5.6 \pm 0.28$ \\
\hline HU 99 & 5 & 1664 & 5.4 & 1640 & 4.9 & & & 1550 & 5.1 & $5.1 \pm 0.28$ \\
\hline HU 110 & 84 & 140 & 5.6 & & & & & 110 & 5.7 & $5.7 \pm 0.07$ \\
\hline do0603 & 98 & 32 & 3.5 & & & 17 & 4.0 & & & $3.8 \pm 0.35$ \\
\hline do0329 & 74 & 200 & 4.1 & & & & & 130 & 4.4 & $4.2 \pm 0.21$ \\
\hline do0351 & 97 & 19 & 3.4 & & & 5 & 3.1 & & & $3.3 \pm 0.21$ \\
\hline HU 180 & 89 & 140 & 2.5 & & & 101 & 1.9 & & & $2.2 \pm 0.42$ \\
\hline
\end{tabular}

${ }^{a}$ decarb: weight percent of the initial mass remaining after $\mathrm{HCl}$ attack 
Table S3: $\delta^{15} \mathrm{~N}, \delta^{13} \mathrm{C}_{\text {carb }}, \mathrm{C}_{\text {org }}, \delta^{13} \mathrm{C}_{\text {org }}, \mathrm{N}$ content and N/C results for late Neoproterozoic samples from Brazil, NW Canada, NE Svalbard and South China. $\delta^{13} \mathrm{C}_{\text {carb }}, \delta^{13} \mathrm{C}_{\text {org }}$ and $\mathrm{C}_{\text {org }}$ are from other studies for South China (Ader et al., 2009) and Brazil (Sansjofre et al., 2011; Sansjofre, 2011).

\begin{tabular}{|c|c|c|c|c|c|c|c|c|c|c|c|c|c|c|c|c|}
\hline \multirow{2}{*}{ Formation } & \multirow{2}{*}{$\begin{array}{c}\text { Stratigr. } \\
\text { height }(m)\end{array}$} & \multirow{2}{*}{ Sample name } & \multirow{2}{*}{$\begin{array}{r}\text { decarb } \\
(w t \%)\end{array}$} & \multicolumn{4}{|c|}{$\delta^{15} \mathrm{~N} \pm 0.1 \%$} & \multicolumn{3}{|c|}{$[\mathrm{N}] \mathrm{ppm}$ decarb ${ }^{1}$} & \multirow{2}{*}{$\begin{array}{c}\text { [N] ppm } \\
\text { bulk }^{2}\end{array}$} & \multicolumn{2}{|c|}{ Corg \% } & \multirow{2}{*}{$\begin{array}{c}\delta^{13} C_{\text {carb }} \\
\pm 0.1 \%\end{array}$} & \multirow{2}{*}{$\begin{array}{l}\delta^{13} C_{\text {org }} \\
\pm 0.1 \%\end{array}$} & \multirow{2}{*}{$\begin{array}{l}\mathrm{C} / \mathrm{N} \\
\text { at }\end{array}$} \\
\hline & & & & $1^{\text {st }}$ & $2^{\text {nd }}$ & $3^{\text {rd }}$ & Avg & $1^{\text {st }}$ & $2^{\text {nd }}$ & Avg & & decarb & Bulk & & & \\
\hline \multicolumn{17}{|c|}{ Yangjiaping section, Yangtze platform, South $\mathrm{China}^{3}$} \\
\hline Datangpo & -93 & XM0101 & 54 & $4.3^{\mathrm{Sb}}$ & & & & & & & $210^{\mathrm{Sb}}$ & 0.23 & 0.11 & -5.2 & -26.4 & 5.9 \\
\hline Datangpo & -92.5 & XM0103 & 12 & $3.3^{\mathrm{Sb}}$ & & & & & & & $1010^{\mathrm{Sb}}$ & 5.6 & 4.89 & & -31.7 & 56 \\
\hline Datangpo & -92 & ઠXM01 & 10 & $4.1^{\mathrm{Sb}}$ & $3.3^{\mathrm{b}}$ & & 3.7 & & & & $770^{b}$ & 3.0 & 2.69 & & -31.3 & 41 \\
\hline Datangpo & -91.5 & XM0107 & 11 & $4.2^{\mathrm{Sb}}$ & $4.7^{\mathrm{b}}$ & 4.0 & 4.3 & 1100 & & & $945^{\mathrm{Sb}}$ & 0.19 & 0.17 & & -29.0 & 2.1 \\
\hline Datangpo & -91 & XM0109 & 9 & $4.6^{\mathrm{b}}$ & & & & & & & $970^{b}$ & 0.13 & 0.12 & -1.8 & -26.2 & 1.4 \\
\hline Doushantuo & 0.4 & do1002 & & $3.2^{\mathrm{Sb}}$ & & & & & & & $70^{\mathrm{Sb}}$ & & & -4.3 & & \\
\hline Doushantuo & 0.7 & do1004 & 94 & 3.8 & & & & 1620 & & & $97^{*}$ & 4.4 & 0.26 & -5.0 & -30.0 & 32 \\
\hline Doushantuo & 1.1 & do1008 & 93 & $4.4^{\mathrm{Sb}}$ & $4.1^{\mathrm{s}}$ & & 4.3 & $875^{S}$ & & & $70^{\mathrm{Sb}}$ & 2.0 & 0.14 & -4.5 & -29.2 & 27 \\
\hline Doushantuo & 3.3 & do1013 & 59 & $5.4^{\mathrm{Sb}}$ & 5.8 & & 5.6 & 1540 & & & $685^{\mathrm{Sb}}$ & 0.33 & 0.14 & -4.9 & -27.6 & 2.3 \\
\hline Doushantuo & 3.8 & do1015 & & $5.3^{\mathrm{Sb}}$ & & & & & & & $590^{\mathrm{Sb}}$ & & & -5.2 & & \\
\hline Doushantuo & 11.7 & HU 99 & 5 & $5.4^{\mathrm{sb}}$ & $4.9^{b}$ & 5.1 & 5.1 & 1630 & & & $1664^{\mathrm{Sb}}$ & 2.6 & 2.44 & & -32.1 & 17 \\
\hline Doushantuo & 15.6 & Sdo 0406 & 6 & $5.8^{\mathrm{b}}$ & & & & & & & $1110^{b}$ & 0.22 & 0.21 & & -29.1 & 2.2 \\
\hline Doushantuo & 38.6 & HU 106 & 52 & $5.6^{\mathrm{Sb}}$ & & & & & & & $336^{b}$ & 0.49 & 0.24 & 2.3 & -26.0 & 8.2 \\
\hline Doushantuo & 0.7 & HU 110 & 84 & $5.6^{\mathrm{sb}}$ & 5.7 & & 5.7 & 700 & & & $140^{\mathrm{Sb}}$ & 4.6 & 0.73 & 5.5 & -25.1 & 61 \\
\hline Doushantuo & 26.6 & do 0603 & 98 & $3.5^{\mathrm{Sb}}$ & $4.0^{S}$ & & 3.8 & $983^{\mathrm{S}}$ & & & $32^{\mathrm{Sb}}$ & 9.6 & 0.17 & 7.7 & -23.4 & 61 \\
\hline Doushantuo & 52.9 & HU 125 & 96 & $4.8^{\mathrm{Sb}}$ & & & & & & & $60^{\mathrm{sb}}$ & 3.9 & 0.16 & 6.9 & -21.1 & 31 \\
\hline Doushantuo & 56.0 & do 0625 & 97 & $3.2^{\mathrm{s}}$ & & & & $560^{S}$ & & & $15.9^{*}$ & 8.6 & 0.24 & 7.2 & -22.4 & 179 \\
\hline Doushantuo & 74.5 & do 0635 & 98 & $4.0^{\mathrm{S}}$ & & & & $400^{5}$ & & & $9.5^{*}$ & 11.9 & 0.28 & 7.3 & -20.9 & 346 \\
\hline Doushantuo & 94.4 & do 0301 & 75 & $5.2^{\mathrm{Sb}}$ & & & & & & & $310^{\mathrm{Sb}}$ & 2.5 & 0.61 & 5.7 & -25.3 & 23 \\
\hline Doushantuo & 115.9 & do 0309 & 99 & 2.8 & & & & 421 & & & $4,1^{*}$ & 2.2 & 0.02 & 4.1 & -28.1 & 60 \\
\hline Doushantuo & 131.0 & do 0319 & 59 & $3.2^{\mathrm{Sb}}$ & & & & & & & $510^{\mathrm{Sb}}$ & 2.2 & 0.90 & 1.8 & -26.9 & 20 \\
\hline Doushantuo & 152.1 & do 0329 & 74 & $4.1^{\mathrm{Sb}}$ & 4.4 & & 4.3 & 490 & & & $200^{\mathrm{Sb}}$ & 1.7 & 0.44 & 2.2 & -26.5 & 26 \\
\hline Dengying & 183.3 & do 0351 & 97 & $3.4^{\mathrm{Sb}}$ & $3.1^{\mathrm{s}}$ & & 3.3 & $180^{S}$ & & & $19^{\mathrm{Sb}}$ & 0.73 & 0.02 & 3.0 & -24.0 & 12 \\
\hline Dengying & 196.0 & HU 180 & 89 & $2.5^{\mathrm{Sb}}$ & $1.9^{\mathrm{S}}$ & & 2.2 & $950^{S}$ & & & $140^{\mathrm{Sb}}$ & 7.7 & 0.83 & -1.4 & -29.5 & 69 \\
\hline Dengying & 216.0 & do1105 & 99.8 & $3.2^{\mathrm{Sb}}$ & & & & & & & $20^{\mathrm{Sb}}$ & 37 & 0.06 & 5.9 & -27.3 & 36 \\
\hline
\end{tabular}


Table S1 continued

\begin{tabular}{|c|c|c|c|c|c|c|c|c|c|c|c|c|c|c|c|c|}
\hline \multirow{2}{*}{ Formation } & \multirow{2}{*}{$\begin{array}{c}\text { Stratigr. } \\
\text { height }(m)\end{array}$} & \multirow{2}{*}{ Sample name } & \multirow{2}{*}{$\begin{array}{c}\text { decarb } \\
(\%)\end{array}$} & \multicolumn{4}{|c|}{$\delta{ }^{15} \mathrm{~N} \pm 0.1 \%$} & \multicolumn{3}{|c|}{$[\mathrm{N}] \mathrm{ppm}$ decarb $^{1}$} & \multirow{2}{*}{$\begin{array}{c}\text { [N] ppm } \\
\text { bulk }^{2}\end{array}$} & \multicolumn{2}{|c|}{ Corg \% } & \multirow{2}{*}{$\begin{array}{c}\delta^{13} C_{\text {carb }} \\
\pm 0.1 \%\end{array}$} & \multirow{2}{*}{$\begin{array}{l}\delta^{13} C_{\text {org }} \\
\pm 0.1 \%\end{array}$} & \multirow{2}{*}{$\begin{array}{l}\mathrm{C} / \mathrm{N} \\
\text { at }\end{array}$} \\
\hline & & & & $1^{\text {st }}$ & $2^{\text {nd }}$ & $3^{\text {rd }}$ & Avg & $1^{\mathrm{st}}$ & $2^{\text {nd }}$ & Avg & & decarb & Bulk & & & \\
\hline \multicolumn{17}{|c|}{ Terconi section, Brazil $^{4}$} \\
\hline Mirassol d'Oeste & 4.2 & TeS 5 & 99.5 & $4.4^{\mathrm{S}}$ & & & & $1073^{S}$ & & & $5^{*}$ & 38 & 0.18 & -4.7 & & 409 \\
\hline Mirassol d'Oeste & 8.2 & Tes 13 & 99.8 & $2.4^{\mathrm{S}}$ & & & & $788^{S}$ & & & $1^{*}$ & 24 & 0.05 & -3.5 & -27.7 & 352 \\
\hline Mirassol d'Oeste & 9.2 & TeS 15 & 95 & $10.0^{S}$ & & & & $283^{S}$ & & & $14^{*}$ & 0.58 & 0.03 & -3.5 & -26.5 & 24 \\
\hline Mirassol d'Oeste & 10.7 & TeS 18 & 93 & 7.9 & & & & 223 & & & $14^{*}$ & 0.88 & 0.06 & -3.9 & -26.8 & 51 \\
\hline Mirassol d'Oeste & 11.7 & Tes 20 & 93 & $6.0^{\mathrm{s}}$ & & & & $2391^{\mathrm{s}}$ & & & $168^{*}$ & 9.0 & 0.63 & -4 & -27.9 & 44 \\
\hline Mirassol d'Oeste & 12.7 & Tes 22 & 92 & $4.6^{\mathrm{S}}$ & $5.1^{\mathrm{s}}$ & & 4.9 & $1101^{\mathrm{s}}$ & $1061^{\mathrm{s}}$ & 1081 & $91^{*}$ & 6.2 & 0.52 & -4.1 & -27.8 & 66 \\
\hline Guia & 15.7 & TeS 28 & 89 & 6.0 & & & & 286 & & & $32^{*}$ & 1.0 & 0.11 & -5.1 & -27.4 & 39 \\
\hline Guia & 16.4 & Tes 30 & 80 & $5.1^{\mathrm{s}}$ & 4.8 & $5.3^{\mathrm{Sb}}$ & 5.1 & $399^{\mathrm{S}}$ & 444 & 422 & $97^{\mathrm{Sb}}$ & 1.1 & 0.23 & -5.1 & -27.5 & 31 \\
\hline Guia & 17.2 & TeS 32 & 89 & 3.2 & & & & 563 & & & $63^{*}$ & 1.3 & 0.15 & -5.2 & -27.6 & 27 \\
\hline Guia & 21.7 & TeS 40 & 92 & 4.0 & 4.1 & & 4.0 & 875 & 637 & & $71^{*}$ & 1.1 & 0.09 & -5.1 & -27.5 & 15 \\
\hline Guia & 27.2 & TeS 42 & 85 & 5.4 & & & & 504 & & & $75^{*}$ & 0.34 & 0.05 & -5.2 & -27.7 & 7.8 \\
\hline Guia & 28.2 & TeS 44 & 88 & 4.3 & 5.1 & & 4.7 & 532 & 636 & 584 & $73^{*}$ & 0.64 & 0.08 & -5 & -27.5 & 13 \\
\hline Guia & 30.7 & Tes 46 & 93 & $2.5^{\mathrm{S}}$ & 3.6 & $3.6^{\mathrm{sb}}$ & 3.2 & $889^{S}$ & 1072 & 980 & $60^{\mathrm{Sb}}$ & 1.8 & 0.13 & -4.8 & -27.9 & 22 \\
\hline Mirassol d'Oeste & 12.8 & $\mathrm{TR}+2.80$ & 93 & 6.9 & & & & 287 & & & $20^{*}$ & 2.1 & 0.15 & -4.9 & -27.9 & 86 \\
\hline Mirassol d'Oeste & 10.6 & $\mathrm{TR}+0.60$ & 91 & 6.8 & 6.8 & & 6.8 & 406 & 249 & 328 & $30^{*}$ & 1.7 & 0.15 & -8.8 & -27.6 & 60 \\
\hline Mirassol d'Oeste & 10.2 & $\mathrm{TR}+0.20$ & 91 & 6.1 & & & & 388 & & & $35^{*}$ & 4.2 & 0.38 & -9.5 & -27.9 & 125 \\
\hline Mirassol d'Oeste & 10 & TR -0.3 & 93 & 10.2 & 10.8 & & 10.5 & 126 & 125 & 126 & $9^{*}$ & 0.41 & 0.03 & -4.1 & -27.6 & 38 \\
\hline Mirassol d'Oeste & 8.3 & TR-1.7 & 96 & 6.2 & 6.9 & & 6.5 & 772 & 710 & 741 & $30^{*}$ & 5.7 & 0.23 & -4.1 & -27.9 & 90 \\
\hline Mirassol d'Oeste & 7.3 & TR-2.7 & 98 & 8.6 & & & & 345 & & & $7^{*}$ & 17 & 0.34 & -3.9 & -27.5 & 575 \\
\hline \multicolumn{17}{|c|}{ Camil section, Brazil ${ }^{4}$} \\
\hline Guia & 112.7 & CAS 1 & 90 & 3.7 & & & & 181 & & & $18^{*}$ & 0.69 & 0.07 & -1.8 & -31.8 & 45 \\
\hline Guia & 111.7 & CAS 2 & 90 & 3.9 & & & & 267 & & & $27^{*}$ & & & -2.0 & & \\
\hline \multicolumn{17}{|c|}{ Carmelo section, Brazil ${ }^{4}$} \\
\hline Guia & 57.6 & CRS 0 & 31 & 4.4 & & & & 155 & & & 108 & 0.07 & 0.05 & -5.3 & -26.5 & 5.1 \\
\hline Guia & 82.9 & CRS 2n & 24 & 4.4 & 4.0 & 3.7 & 4.0 & 260 & 270 & 265 & 201 & 0.12 & 0.09 & -5.1 & -27.5 & 5.5 \\
\hline Guia & 84.8 & CRS 3 & 63 & 3.4 & & & & 203 & & & 75 & 0.11 & 0.04 & -4.9 & -28.5 & 6.1 \\
\hline Guia & 85.6 & CRS 4 & 20 & 3.2 & & & & 278 & & & 224 & 0.12 & 0.10 & -4.5 & -31.8 & 5.0 \\
\hline Guia & 107.3 & CRS 5 & 64 & 4.2 & 3.9 & & 4.1 & 284 & 299 & 292 & 108 & 0.29 & 0.10 & -4.1 & -31.9 & 11 \\
\hline
\end{tabular}


Table S1 continued

\begin{tabular}{|c|c|c|c|c|c|c|c|c|c|c|c|c|c|c|c|c|}
\hline \multirow{2}{*}{ Formation } & \multirow{2}{*}{$\begin{array}{c}\text { Stratigr. } \\
\text { height }(m)\end{array}$} & \multirow{2}{*}{ Sample name } & \multirow{2}{*}{$\begin{array}{c}\text { decarb } \\
(\%)\end{array}$} & \multicolumn{4}{|c|}{$\delta^{15} \mathrm{~N} \pm 0.1 \%$} & \multicolumn{3}{|c|}{$[\mathrm{N}] \mathrm{ppm}^{\mathrm{decarb}}{ }^{1}$} & \multirow{2}{*}{$\underset{\text { bulk }^{2}}{[\mathrm{~N}] \mathrm{ppm}^{2}}$} & \multicolumn{2}{|c|}{ Corg \% } & \multirow{2}{*}{$\begin{array}{c}\delta^{13} C_{\text {carb }} \\
\pm 0.1 \%\end{array}$} & \multirow{2}{*}{$\begin{array}{l}\delta^{13} C_{\text {org }} \\
\pm 0.1 \% \text { o }\end{array}$} & \multirow{2}{*}{$\begin{array}{l}\mathrm{C} / \mathrm{N} \\
\text { at }\end{array}$} \\
\hline & & & & $1^{\text {st }}$ & $2^{\text {nd }}$ & $3^{\text {rd }}$ & Avg & $1^{\text {st }}$ & $2^{\text {nd }}$ & Avg & & decarb & Bulk & & & \\
\hline Guia & 110.8 & CRS 7 & 69 & 5.5 & & & & 97 & & & 30 & 0.09 & 0.03 & -3.9 & -31.0 & 10 \\
\hline Guia & 111.6 & CRS 8 & 98 & $4.6^{\mathrm{S}}$ & & & & $149^{S}$ & & & $4^{*}$ & 0.36 & 0.01 & 0.0 & -28.2 & 28 \\
\hline Guia & 120.6 & CRS 11 & 97 & 3.9 & & & & 390 & & & $10^{*}$ & 0.53 & 0.01 & -3.1 & -31.0 & 16 \\
\hline Guia & 140.1 & CRS 13 & 81 & 4.2 & 3.6 & & 3.9 & 203 & 196 & 199 & 38 & 0.19 & 0.04 & -2.0 & -30.1 & 11 \\
\hline Guia & 159.2 & CRS 16 & 60 & $5.1^{\mathrm{s}}$ & 4.7 & & 4.9 & $336^{\mathrm{S}}$ & 301 & 319 & 134 & 0.46 & 0.18 & -2.0 & -32.0 & 16 \\
\hline Guia & 167.1 & CRS 19 & 96 & 2.6 & & & & 410 & & & $16^{*}$ & 0.67 & 0.03 & -0.7 & -30.4 & 19 \\
\hline Guia & 170.6 & CRS 20 & 98 & 2.7 & & & & 1264 & & & $21^{*}$ & 3.7 & 0.06 & -1.0 & -31.2 & 34 \\
\hline Guia & 178.6 & CRS 23 & 93 & & & & & 151 & & & $10^{*}$ & 0.63 & 0.04 & -0.5 & -30.8 & 48 \\
\hline Guia & 181.2 & CRS 24 & 83 & 5.1 & & & & 369 & & & 68 & 0.96 & 0.16 & -0.5 & -32.1 & 28 \\
\hline Guia & 191.8 & CRS 28 & 96 & & & & & 124 & & & $5^{*}$ & 0.22 & 0.01 & -0.3 & -28.2 & 21 \\
\hline Guia & 197.1 & CRS 30 & 20 & $5.8^{S}$ & & & & $380^{\mathrm{S}}$ & & & 304 & 0.76 & 0.60 & -0.9 & -31.8 & 23 \\
\hline Guia & 201.3 & CRS 32 & 76 & 5.4 & & & & 145 & & & 35 & 0.21 & 0.05 & -0.3 & -29.9 & 17 \\
\hline Guia & 207.7 & CRS 35 & 90 & & & & & 98 & & & $10^{*}$ & 0.14 & 0.01 & -0.0 & -28.7 & 16 \\
\hline \multicolumn{17}{|c|}{ Copacel section, Araras platform, Brazil ${ }^{4}$} \\
\hline Guia & 35.1 & NOS 13 & 98 & 4.8 & & & & 425 & & & $7^{*}$ & 0.57 & 0.01 & -0.2 & -28.1 & 16 \\
\hline Guia & 76.2 & NOS 8 & 68 & & & & & 101 & & & 32 & 0.09 & 0.03 & -3.9 & -29.7 & 10 \\
\hline Guia & 201.3 & $\mathrm{CP} 1$ & 89 & 2.3 & & & & 146 & & & & 0.32 & 0.03 & -1.0 & -30.8 & \\
\hline Guia & 259.3 & CP13 & 95 & 2.2 & & & & 1009 & & & $48^{*}$ & 2.1 & 0.10 & -0.8 & -31.2 & 24 \\
\hline Guia & 333.8 & CP 51 & 75 & 5.0 & & & & 545 & & & 138 & 1.5 & 0.38 & -3.0 & -32.6 & 32 \\
\hline \multicolumn{17}{|c|}{ Northeast Svalbard composite section ${ }^{5}$} \\
\hline Dracoisen & 19.4 & G136-19.4 & & 4.1 & & & & 540 & 580 & 560 & & 0.54 & & & -33.9 & 11 \\
\hline Dracoisen & 24.1 & G136-24.1 & & 4.7 & 4.5 & & 4.6 & 490 & 490 & 490 & & 0.57 & & & -34.1 & 14 \\
\hline Dracoisen & 105 & G436-105 & & 5.2 & & & & 700 & & & & & & & & \\
\hline Dracoisen & 88 & G436-88 & & 5.2 & & & & 720 & & & & 0.28 & & & -31.2 & 4.5 \\
\hline Dracoisen & 64 & G436-64 & & 5.6 & & & & 600 & & & & 0.99 & & & -34.9 & 19 \\
\hline Dracoisen & 42 & G436-42 & & 4.3 & & & & 390 & & & & 0.29 & & & -32.6 & 8.7 \\
\hline Dracoisen & 159 & G306-159 & & 5.3 & & & & 1080 & & & & & & & & \\
\hline Dracoisen & 143 & G306-143 & & 5.8 & & & & 700 & & & & 1.26 & & & & \\
\hline
\end{tabular}


Table S1 continued

\begin{tabular}{|c|c|c|c|c|c|c|c|c|c|c|c|c|c|c|c|c|}
\hline \multirow{2}{*}{ Formation } & \multirow{2}{*}{$\begin{array}{c}\text { Stratigr. } \\
\text { height }(\mathrm{m})\end{array}$} & \multirow{2}{*}{ Sample name } & \multirow{2}{*}{$\begin{array}{c}\text { decarb } \\
(\%)\end{array}$} & \multicolumn{4}{|c|}{$\delta^{15} N \pm 0.1 \%$} & \multicolumn{3}{|c|}{$[\mathrm{N}]$ ppm decarb $^{1}$} & \multirow{2}{*}{$\begin{array}{c}\text { [N] ppm } \\
\text { bulk }^{2}\end{array}$} & \multicolumn{2}{|c|}{ Corg \% } & \multirow{2}{*}{$\begin{array}{c}\delta^{13} C_{\text {carb }} \\
\pm 0.1 \%\end{array}$} & \multirow{2}{*}{$\begin{array}{l}\delta^{13} C_{\text {org }} \\
\pm 0.1 \% \text { o } \\
\end{array}$} & \multirow{2}{*}{$\begin{array}{l}\mathrm{C} / \mathrm{N} \\
\text { at }\end{array}$} \\
\hline & & & & $1^{\mathrm{st}}$ & $2^{\text {nd }}$ & $3^{\text {rd }}$ & Avg & $1^{\text {st }}$ & $2^{\text {nd }}$ & Avg & & decarb & Bulk & & & \\
\hline Macdonaldryggen & -25 & G435-25 & & 6.3 & & & & 320 & & & & 0.31 & & & -30.4 & 11 \\
\hline Macdonaldryggen & -35 & G435-35 & & 4.2 & & & & & & & & & & & & \\
\hline Macdonaldryggen & -56 & G435-56 & & 4.8 & & & & 670 & & & & 0.55 & & & -32.7 & 9.6 \\
\hline Macdonaldryggen & -66 & G435-66 & & 5.5 & & & & 680 & & & & 0.68 & & & -32.6 & 12 \\
\hline Macdonaldryggen & -76 & G435-76 & & 4.6 & & & & 680 & & & & & & & & \\
\hline Macdonaldryggen & -79.5 & G435-79.5 & & 5.5 & 5.3 & & 5.4 & 610 & 590 & 600 & & 0.64 & & & -32.4 & 12 \\
\hline Russøya Mb. & 114 & G406-35 & & 4.2 & 4.5 & & 4.4 & 1280 & 1240 & 1260 & & 0.42 & & & & \\
\hline Russøya Mb. & 106.5 & G406-42 & & 4.2 & & & & 450 & & & & 6.56 & & & -27.9 & 170 \\
\hline Russøya Mb. & 43.5 & P5014-43.5 & & 4.7 & & & & 630 & & & & & & & & \\
\hline \multicolumn{17}{|c|}{ Northwest Canada composite section ${ }^{6}$} \\
\hline Sheepbed & 94 & G4-94 & & 2.6 & & & & 1060 & & & & 1.13 & & & -30.8 & 11 \\
\hline Sheepbed & 73 & G4-93 & & 3.7 & & & & 590 & & & & 0.62 & & & -30.3 & 10 \\
\hline Sheepbed & 36 & G4-36 & & 3.3 & & & & 680 & & & & 0.33 & & & -29.4 & 4.9 \\
\hline Sheepbed & 8 & G4-8 & & 3.1 & & & & 650 & & & & 0.35 & & & -31.3 & 5.4 \\
\hline Twitya & 163 & F849.163 & & $3.5^{\mathrm{b}}$ & & & & & & & $1030^{b}$ & & & & & \\
\hline Twitya & 135 & F849.135 & & $2.4^{\mathrm{b}}$ & & & & & & & $930^{\mathrm{b}}$ & & & & & \\
\hline Twitya & 87 & F849.87 & & $2.5^{\mathrm{b}}$ & & & & & & & $650^{\mathrm{b}}$ & & & & & \\
\hline Twitya & 46 & F849.46 & & $2.1^{\mathrm{b}}$ & & & & & & & $510^{\mathrm{b}}$ & & & & & \\
\hline
\end{tabular}

Most $\mathrm{N}$ content and $\delta^{15} \mathrm{~N}$ measurements were performed on decarbonated samples by conventional mass spectrometry. $\mathrm{N}$ content and $\delta^{15} \mathrm{~N}$ measurements performed on bulk samples are indicated by ${ }^{\mathrm{b}}$ and measurements performed using the static mass spectrometry are indicated by ${ }^{\mathrm{s}}$.

1 [N] ppm decarb: values correspond to the direct measurement of the nitrogen content in the decarbonated residu.

[N] ppm decarb: values correspond to the direct measurement of the nitrogen content in the decarbonated residu.
$[\mathrm{N}] \mathrm{ppm}$ bulk : values correspond either to direct measurement of the nitrogen content in bulk samples or in the recalculated nitrogen content in the bulk samples from the nitrogen content in the decarbonated residu and the mass pourcent of mass loss after decarbonatation (decarb \%).

* indicates most probably underestimated $\mathrm{N}$ content in bulk rocks, owing to possible mass loss during the decarbonatation procedure (see method section in the main text

${ }^{3}$ For the South China data, the 0 datum correspond to the contact between the cap carbonate and the Nantuo Diamictite.

${ }^{4}$ For the Brazilian data, the datums are as follows, $0=$ contact with the Marinoan Diamictites of the Puga Formation for Terconi, Carmelo and Copacel sections. For Camil section, $0=$ firt outcrop of the Guia Formation observed in Camil quarry, which is $114 \mathrm{~m}$ below the Guia-Serra Do Quilombo transition.

${ }^{5}$ For the Svalbard data, the datums are as follows: for the Dracoisen formation, $0=$ based of the formation; for the Macdonaldryggen Member, $0=$ the top of the member; for the Russøya Member, 0 = the base of the member

${ }^{6}$ For the NW Canada data, the $0 \mathrm{~m}$ datums are the base of each formation. 